\title{
ASSESSMENT OF THE RAINFALL STORM EVENTS OF JANUARY 2010 AND MARCH 2014 FOR THE CATCHMENT MODELING OF WADI EL ARISH AND WADI WARDAN BASINS, SINAI, EGYPT
}

\author{
Nahla A. Morad \\ Department of Hydrology, Desert Research Center, El-Matareya, \\ Cairo, Egypt \\ E-mail: nahlamorad@ hotmail.com
}

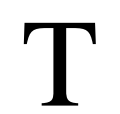

he aim of this article is to analyze and assess two rainfall storms characteristics representing two different seasons i.e. winter (January 2010) and spring (March 2014) and the response of both Wadi El Arish $\left(21787 \mathrm{~km}^{2}\right)$ and Wadi Wardan $\left(1385 \mathrm{~km}^{2}\right)$ catchments in Sinai to such storms. Wadi El Arish, is debouching towards the Mediterranean Sea at north, and is dominated by carbonate rocks, while Wadi Wardan $\left(1454 \mathrm{~km}^{2}\right)$ is running towards the Gulf of Suez at west, and is dominated by clastic sediments. This study is based on the determination of the hydrologic parameters and variables of both basins as well as the analysis of rainfall data for the purpose of catchment modeling. The HEC-HMS model (version 4) is used to estimate the peak discharge and runoff volume occurred in each sub-basin (eight in Wadi El Arish and four in Wadi Wardan). The results show that the storms have not the same behavior neither spatially nor temporally, where they differ from sub-basin to another and from time to time. The results of storm simulation show that flash flood characteristics are highly variable from season to season in terms of storm amount and duration, runoff volume, runoff depth and runoff coefficient. Wadi El Arish received a considerable amount of runoff water during the storm of $2010\left(107.68 * 10^{6} \mathrm{~m}^{3}\right)$, with a peak discharge equals to $1382.5 \mathrm{~m}^{3} / \mathrm{s}$, while in the storm of 2014 the total runoff volume was only $16.1 * 10^{6} \mathrm{~m}^{3}$ and the peak discharge was $279.1 \mathrm{~m}^{3} / \mathrm{s}$. El Roak sub-basin $\left(5988 \mathrm{~km}^{2}\right)$, which represents the largest sub-basin in Wadi El Arish running from south to north, produced the maximum discharge (996.2 and $229.9 \mathrm{~m}^{3} / \mathrm{s}$ ) and consequently the maximum runoff volume $\left(61.6^{*} 10^{6}\right.$ and $\left.13.3^{*} 10^{6} \mathrm{~m}^{3}\right)$ for storms 2010 and 2014, respectively. The runoff coefficients in El Roak sub-basin are 27.65 and $15.88 \%$ for storms 2010 and 2014, respectively. This means that more than $27 \%$ of the rainfall transform to runoff in this sub-basin. In Wadi Wardan, the peak discharges are $312 \mathrm{~m}^{3} / \mathrm{s}$ and $52.1 \mathrm{~m}^{3} / \mathrm{s}$ and the total runoff volume are $8.9^{*} 10^{6} \mathrm{~m}^{3}$ and $1.5^{*} 10^{6} \mathrm{~m}^{3}$ 
for storms 2010 and 2014, respectively. Somar sub-basin $\left(441 \mathrm{~km}^{2}\right)$, sub- basins in the upstream of Wadi Wardan and run in the east-west direction, have the maximum discharge (180.9 and $\left.27.1 \mathrm{~m}^{3} / \mathrm{s}\right)$ and runoff volume $\left(4.6^{*} 10^{6}\right.$ and $\left.0.76^{*} 10^{6} \mathrm{~m}^{3}\right)$ for storms 2010 and 2014 , respectively. The runoff coefficient is in Somar sub-basin are $36.55 \%$ and $13.04 \%$ for storms 2010 and 2014, respectively. From the catchment- storm modeling, one can recommend constructing two storage dams at the outlet of El Roak and Somar sub-basins, where the runoff volume of these sub-basins represents about 55\% of the total runoff volume, in order to protect the urban areas from the occasionally flash flood risk.

Keywords: Rainfall storms, runoff, catchment modeling, Wadi El Arish, Wadi Wardan, Sinai

The selected catchments are frequently subjected to severe flash floods as a result of heavy rainfall in a short duration period. The aim of the present work is to analyze and assess the possible effects of two flash flood events; i.e. January 2010 and March 2014. The surface runoff water, which can replenish the shallow groundwater aquifers, in both Wadi El Arish $\left(21787 \mathrm{~km}^{2}\right)$ and Wadi Wardan $\left(1385 \mathrm{~km}^{2}\right)$ catchments has been estimated using the HEC-HMS model (version 4). These floods caused a great damage of the infrastructure in both El Arish city at north and Abu Swira town at west, where many buildings have been built in the main trunk of the Wadies without any protection against flooding. Generally, flash floods in desert areas are characterized by high velocity and short duration with a sharp peak discharge (JICA, 1999).

The base map of the study area (Fig. 1) was compiled from the available geological map of Sinai (1994) (scale 1:250,000). Wadi El Arish flows generally to the north, with Length about $280 \mathrm{~km}$ from its upstream (El Egma plateau) until its downstream (Mediterranean Sea), while Wadi Wardan runs to the west with a length of about $60 \mathrm{~km}$ and debouches in the Gulf of Suez

The study area has been subjected to intensive studies by many researchers during the last years. Among them are; Dames and Moore (1981), Abdel Monsef (1991), JICA (1999), Morad (2000), Abdel-Lattif and Sherief (2010), Moawad (2013), Shabana (2014) and Abo Shaala (2016). On the other hand, several studies are cited in the literature relating to rainfallrunoff relationship and hydrograph generation using HEC-HMS software. Among these are; Arekhi (2012), Halwatura and Najim (2013), Choudhari et al. (2014), Gebre (2015) and Fathy et al. (2015).

Egyptian J. Desert Res., 66, No. 1, 137-168 (2016) 


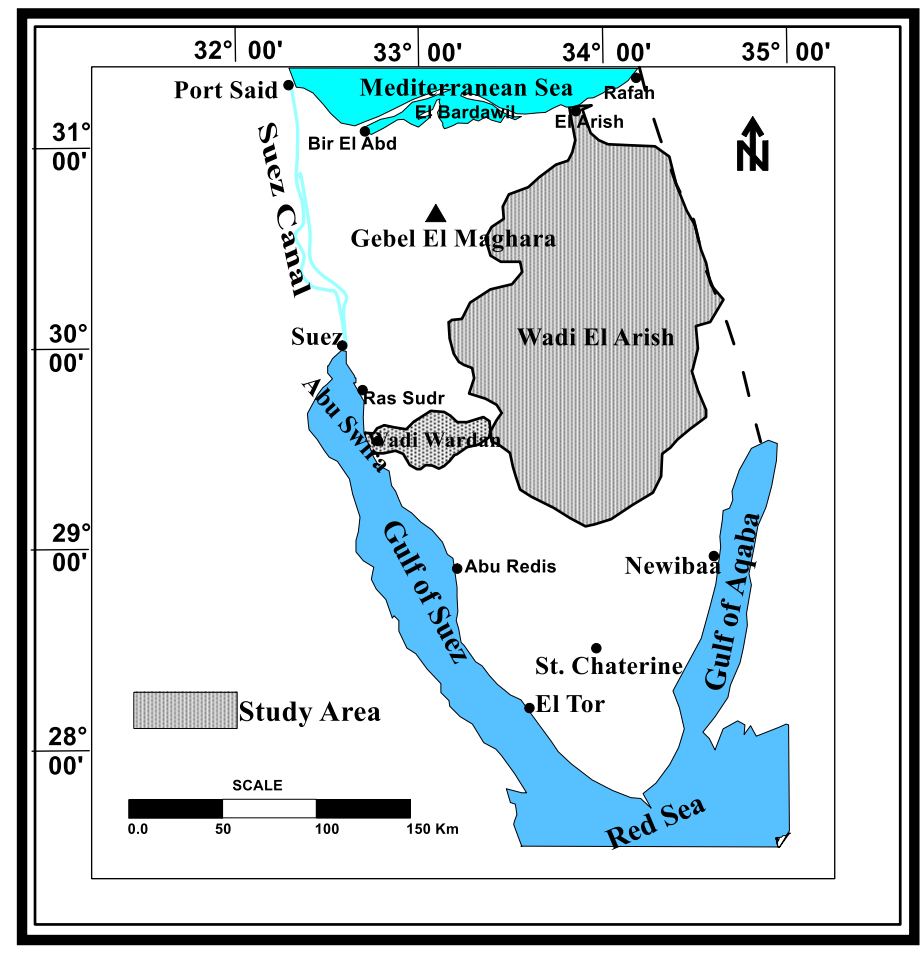

Fig. (1). Location map of Wadi El Arish and Wadi Wardan basins.

\section{Geomorphology and Geology of Study Area}

Three main geomorphic units are distinguished in the study basins as follows (Fig. 2) (Dames and Moore, 1981; Sayed and Abdel Latif, 1985 and Shabana, 2014):

\section{The Central Plateau (EI Tih and El Egma)}

The elevated plateaus (El Tih and El Egma), which are located in the upstream part of Wadi El Arish, cover an area of about $13000 \mathrm{~km}^{2}$ that is considered as one of the most important watershed areas in Sinai. The maximum ground elevation (above mean sea level) of these plateaus attains about $+1626 \mathrm{~m}$ at Gebel Genina in the southern portion, while the minimum level reaches $+523 \mathrm{~m}$ at Gebel El Shaira in the northern portion. In central Sinai, El Tih-El Egma plateaus area, $+914 \mathrm{~m}$ above sea level is affected by faulting, where to the north from this region, an east-west trending shear zone of a major slip fault with up to $2.5 \mathrm{~km}$ displacement called Raqabet El Naam fault. The bedrock of this area is predominantly composed of horizontally bedded Middle and Lower Cretaceous sandstones and limestone and Eocene limestone. In general, the Cretaceous strata on the periphery of the area form a horseshoe pattern around the Eocene limestone. Wadi El Arish and its tributaries cut deep and narrow gorges into the Cretaceous and

Egyptian J. Desert Res., 66, No. 1, 137-168 (2016) 
Eocene limestone and sandstones. Alluvium, and eolian sand deposits make up the surficial geology of this area

For Wadi Wardan, the central plateau represents the upstream part of the wadi. Its surface is barren and formed of Upper Cretaceous Limestone. The Plateau rises to about more than $800 \mathrm{~m}$ and is dissected on its western slopes by several dry vallies that drain winter runoff westward.

\section{The Hilly Area}

The hilly area occupies the northeastern portion of Sinai (midstream of Wadi El Arish). It covers an area of about $17,000 \mathrm{~km}^{2}$. It is characterized by local isolated hills as Gebel El Magharah $(+750 \mathrm{~m})$, Gebel Yelleq $(+1087 \mathrm{~m})$, Gebel El Halal $(+892 \mathrm{~m})$, Gebel El Giddi $(+840 \mathrm{~m})$, Gebel El Minsherah $(+570 \mathrm{~m})$ and Gebel Talat El Badan $(+400 \mathrm{~m})$. These mountains are formed of elongated doubly plunging dome-like anticlines arranged in several rows running in northeast-southwest direction (Syrian Arc trend). The strata that form the anticlines are predominantly Cretaceous limestone, dolomite marl and sandstone. Outliers of Eocene chalk and limestone occur in the synclinal lowlands between the anticlines or along their flanks. The middle and lower Cretaceous limestone and sandstone form the uplifted areas of the anticlines. Alluvial deposits and sand dune of Quaternary age occur in major portions of this area.

\section{The Northern and Western Coastal Plains}

The coastal plain occupies the northern and northwestern portions of Sinai (downstream part of Wadi El Arish). The surface of this area is gently undulated and is marked by stranded ridges of thick sand dunes. The surface deposits in this sector belong to the Quaternary age, including Pleistocene and Holocene. The Pleistocene consists of fanglomerate and alluvial, while the Holocene consists of playa and sand dune deposits.

For Wadi Wardan, this plain is located in the middle stream and the downstream part of the Wadi. On the extreme west, the coastal plain extends parallel to the Gulf Coast in the form of narrow belt of drift sands and small scattered sand dunes. The coastal plain is covered with recent deposits in the form of coarse sand and gravel in the midstream and loam and sand downstream. The shallow subsurface succession consists mainly of Pliocene and Pleistocene gravel, sand and clay.

\section{MATERIALS AND METHODS}

\section{Catchment Characteristics}

The watershed characteristics of the studied Wadies are evaluated using the digital elevation model (DEM) of Sinai (Fig. 3) with $30 \mathrm{~m}$ resolution and Geographic Information System (GIS) Software (ILWIS 3.4, 2007).

Egyptian J. Desert Res., 66, No. 1, 137-168 (2016) 


\section{Wadi El Arish}

Wadi El Arish represents the largest drainage basin in Sinai. It covers an area of approximately $21787 \mathrm{~km}^{2}$, i.e. $36 \%$ of the total area of Sinai Peninsula .It debouches into the Mediterranean Sea. It is located in the central and northern parts of the peninsula (between Long. $33^{\circ} 10^{\prime}$ and $34^{\circ}$ $40^{\prime} \mathrm{E}$ and Lat. $29^{\circ} 00^{\prime}$ and $31^{\circ} 00^{\prime} \mathrm{N}$ ). The main channel flows generally towards the north, having a length about $280 \mathrm{~km}$. Using the GIS Software (ILWIS 3.4, 2007) the whole drainage basin of Wadi El Arish is divided into 8 sub- basins of different areas and different features (Table 1 and Fig. 4). It is noticed that El Roak sub-basin, which run from south to north, represents the largest sub-basin, followed by El Hassana and El Bruk sub-basin (run from the west to the east).

According to the digital elevation model (DEM) of Sinai, the elevations of Wadi El Arish range from $1300 \mathrm{~m}$ above mean sea level at El Egma Plateau (upstream area) to the sea level at its downstream portion (Mediterranean Sea).

A longitudinal profile along the main trunk of Wadi El Arish is plotted (Fig. 5), where the following can be noticed;

- Wadi El Arish is characterized by steep slope in the upstream part of the basin (155 km from its origin), where the slope is about 6.5 $\mathrm{m} / \mathrm{km}$, while in the midstream and downstream of the Wadi, the slope of the main trunk gets more gentle $(2.1 \mathrm{~m} / \mathrm{km})$. This slope gradient variation is due to the structural role and the geomorphic feature (Hassan, 2002).

- The tributaries of three sub-basins (El Bruk, El Roak and Aqabah) are joined in one point, which represents the northern edge of El Egma plateau, indicating the following;

i. There is a change in slope in this point from 6.5 to $2.1 \mathrm{~m} / \mathrm{km}$

ii. The groundwater possibility at this points is quite high.

iii. This point receives runoff from three sub-basins, where runoff water harvesting is quite promising.

- In the downstream of the Wadi, where the slope is gentle, the groundwater recharge by surface runoff is quite expected due to low flow velocity.

- The widest part of Wadi El Arish $(153 \mathrm{~km})$ is located at the northern edge of El Egma plateau (latitude $\left.30^{\circ} 00^{\prime} 00^{\prime \prime}\right)$, while in the downstream of the wadi, the width gets very narrow $(5.0 \mathrm{~km})$ due to the presence of Gebel El Hallal, which acts as a gorge. In other words, the delta of Wadi El Arish, is very narrow comparing with the width of the basin itself. 


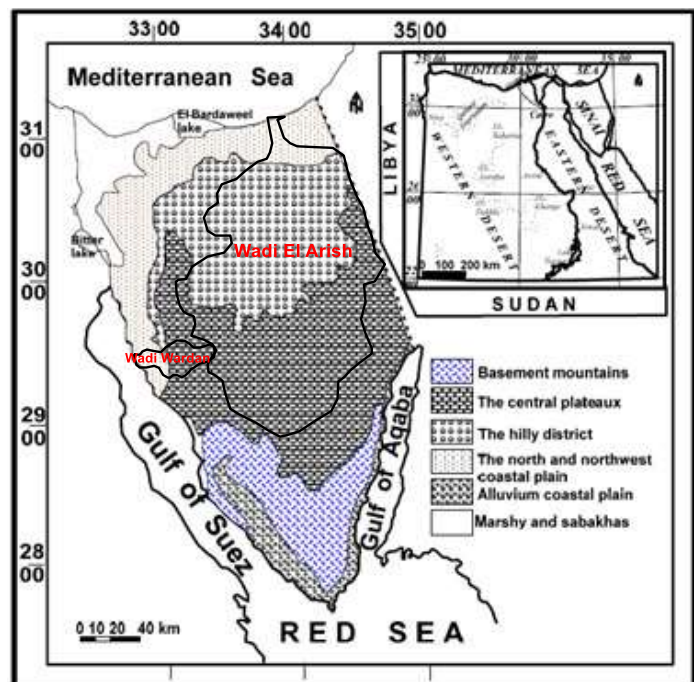

Fig. (2). Geomorphologic map of Sinai (Shabana, 2014).

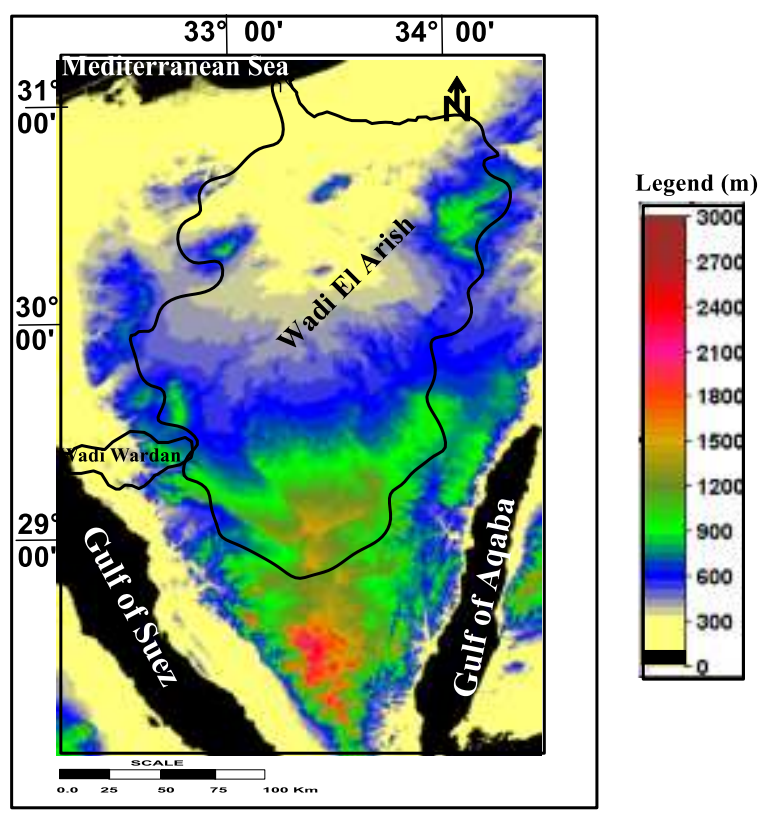

Fig. (3). Digital Elevation Model (DEM) of Sinai.

Egyptian J. Desert Res., 66, No. 1, 137-168 (2016) 
Table (1). Main parameters of Wadi El-Arish sub-basins.

\begin{tabular}{ccccccc}
\hline $\begin{array}{c}\text { Sub- } \\
\text { basin }\end{array}$ & Name & $\begin{array}{c}\text { Area } \\
\left(\mathbf{k m}^{2}\right)\end{array}$ & $\begin{array}{c}\text { Basin } \\
\text { length }(\mathbf{k m})\end{array}$ & $\begin{array}{c}\text { Upstream } \\
\text { elevation }(\mathbf{m})\end{array}$ & $\begin{array}{c}\text { Downstream } \\
\text { elevation }(\mathbf{m})\end{array}$ & $\begin{array}{c}\text { Average } \\
\text { slope }(\mathbf{m} / \mathbf{k m})\end{array}$ \\
\hline 1 & El Hasana & 3600 & 92 & 1070 & 50 & 11.08 \\
2 & El Bruk & 3310 & 90.7 & 922 & 300 & 6.85 \\
3 & El Roak & 5988 & 160 & 1300 & 300 & 6.21 \\
4 & Aqabah & 2267 & 110 & 1200 & 300 & 8.18 \\
5 & Abu Qurayah & 3220 & 81 & 970 & 235 & 9.10 \\
6 & El Qusiama & 1145 & 79.2 & 957 & 175 & 9.87 \\
7 & Umm- Shihan & 2140 & 170 & 880 & 50 & 4.88 \\
8 & Delta & 117 & 20 & 50 & zero & 2.50 \\
\hline
\end{tabular}

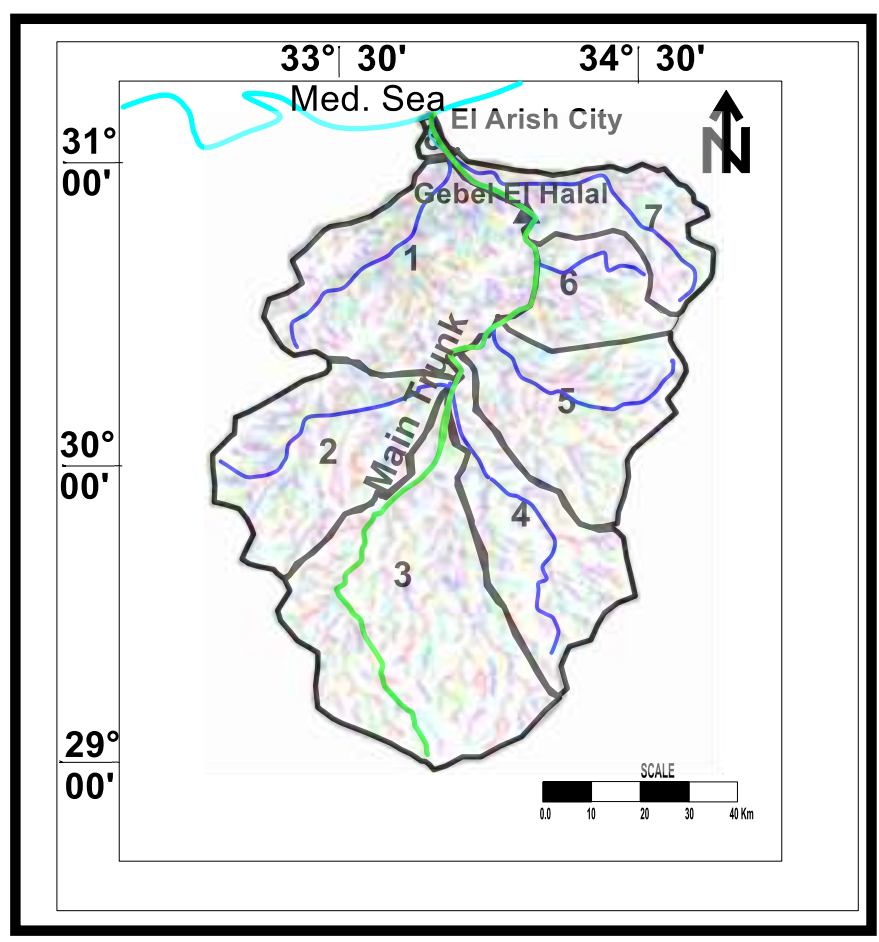

Fig. (4). Sub-basins and main drainage lines of Wadi El-Arish. 


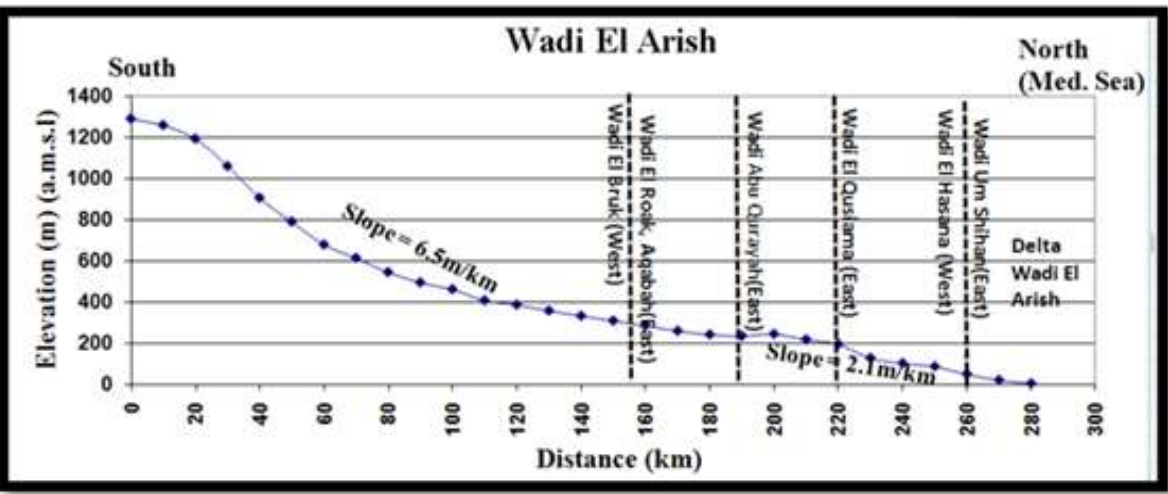

Fig. (5). Longitudinal profile of Wadi El Arish.

\section{Wadi Wardan}

Wadi Wardan originates in the western edge of EL-Egma plateau and discharges in the eastern side of Gulf of Suez, covering an area of about $1385 \mathrm{~km}^{2}$. It is located between Long. $32^{\circ} 35^{\prime}$ and $33^{\circ} 15^{\prime} \mathrm{E}$ and Lat. $29^{\circ} 20^{\prime}$ and $29^{\circ} 40^{\prime} \mathrm{N}$. Wadi Wardan is divided into four sub-basins according to its drainage patterns (Fig. 6 and Table 2). A longitudinal profile along the main trunk of Wadi Wardan is plotted (Fig. 7). The elevations in Wadi Wardan range from $800 \mathrm{~m}$ above mean sea level in the upstream to $4.0 \mathrm{~m}$ in its downstream (Gulf of Suez). The length of the main channel is $60 \mathrm{~km}$. The sedimentary rocks, which prevail in the Wadi range in age from Upper Cretaceous to Quaternary. The Upper Cretaceous covers the upstream part of the wadi, representing the surface runoff part in the Wadi, where it is characterized by very steep slope $(17.7 \mathrm{~m} / \mathrm{km})$. The midstream of the Wadi is covered by lower Miocene sandstone, belonging to the Tertiary age. The slope of the main trunk gets less steep than the upstream $(10 \mathrm{~m} / \mathrm{km})$. The delta of the Wadi is covered by Quaternary deposits, which comprises the main aquifer in the downstream of the Wadi. It is composed of alluvial deposits, which are made up of gravel intercalated with varicolored clay and calcareous sandstone (Hassanein, 1989 and Misak et al., 1995).

Egyptian J. Desert Res., 66, No. 1, 137-168 (2016) 


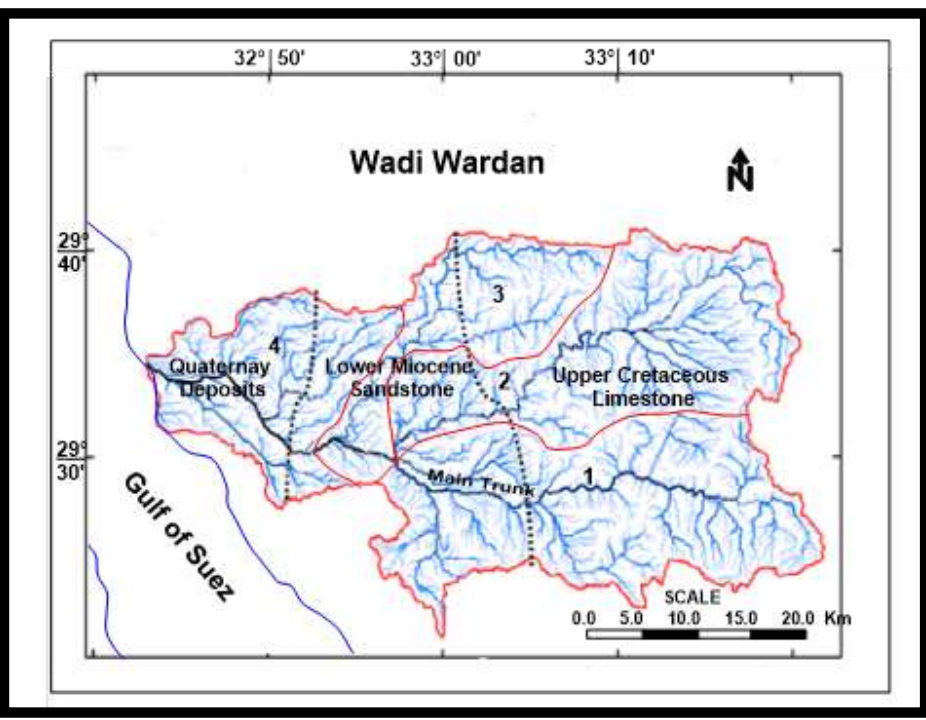

Fig. (6). Drainage map of Wadi Wardan.

Table (2). Main parameters of Wadi Wardan sub-basins.

\begin{tabular}{ccccccc}
\hline $\begin{array}{c}\text { Sub- } \\
\text { basin }\end{array}$ & Name & $\begin{array}{c}\text { Area } \\
\left.\mathbf{( k m}^{\mathbf{2}}\right)\end{array}$ & $\begin{array}{c}\text { Basin length } \\
(\mathbf{k m})\end{array}$ & $\begin{array}{c}\text { Upstream } \\
\text { elevation }(\mathbf{m})\end{array}$ & $\begin{array}{c}\text { Downstream } \\
\text { elevation }(\mathbf{m})\end{array}$ & $\begin{array}{c}\text { Average } \\
\text { slope }(\mathbf{m} / \mathbf{k m})\end{array}$ \\
\hline 1 & Somar & 441 & 45 & 720 & 134 & 13.0 \\
2 & El Fawqiyah & 476 & 55 & 910 & 134 & 14.2 \\
3 & El Rahah & 212 & 35 & 697 & 100 & 17.0 \\
4 & Delta & 256 & 23 & 100 & zero & 4.35 \\
\hline
\end{tabular}

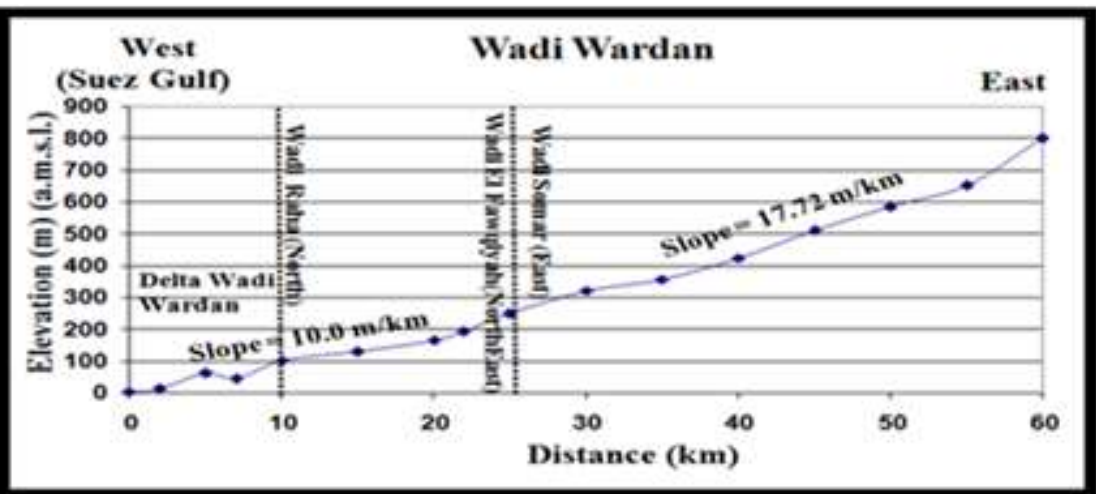

Fig. (7). Longitudinal profile of Wadi Wardan.

In order to understand the main difference between Wadi El Arish and Wadi Wardan, a brief comparison for the main characteristics of these Wadies are given below (Table 3).

Egyptian J. Desert Res., 66, No. 1, 137-168 (2016) 
Table (3). Comparative study of the main characteristics of Wadis El Arish and Wardan.

\begin{tabular}{|c|c|c|c|}
\hline Characteristics & Wadi & Wadi El Arish & Wadi Wardan \\
\hline \multicolumn{2}{|l|}{ Location } & South to North Sinai & South Sinai \\
\hline \multicolumn{2}{|l|}{ Area $\left(\mathrm{km}^{2}\right)$} & 21787 & 1385 \\
\hline \multicolumn{2}{|c|}{ Length of main trunk $(\mathrm{km})$} & 280 & 60 \\
\hline \multicolumn{2}{|c|}{ Perimeter $(\mathrm{km})$} & 1214 & 240 \\
\hline \multicolumn{2}{|l|}{ Stream Order } & 8 & 7 \\
\hline \multicolumn{2}{|c|}{ Maximum Elevation (m) } & 1300 & 800 \\
\hline \multirow{2}{*}{$\begin{array}{l}\text { Basin slope } \\
(\mathrm{m} / \mathrm{km})\end{array}$} & Upstream & 6.5 & 17.7 \\
\hline & Downstream & 2.1 & 10 \\
\hline \multicolumn{2}{|l|}{ Origin } & $\begin{array}{c}\text { El Egma and El Tih } \\
\text { Plateau }\end{array}$ & $\begin{array}{c}\text { El Egma and El Tih } \\
\text { Plateau }\end{array}$ \\
\hline \multirow{3}{*}{ Surface geology } & Upstream & $\begin{array}{l}\text { Mediterranean Sea } \\
\text { limestone rocks } \\
\text { (Upper Cretaceous) }\end{array}$ & $\begin{array}{c}\text { Gulf of Suez } \\
\text { Upper Cretaceous } \\
\text { Limestone }\end{array}$ \\
\hline & Midstream & $\begin{array}{l}\text { Marl and Sandstone } \\
\text { (Miocene) }\end{array}$ & $\begin{array}{l}\text { Lower Miocene } \\
\text { sandstone }\end{array}$ \\
\hline & Downstream & $\begin{array}{l}\text { Alluvium deposits } \\
\text { (Quaternary) }\end{array}$ & $\begin{array}{l}\text { Quaternary } \\
\text { deposits }\end{array}$ \\
\hline
\end{tabular}

\section{RESULTS AND DISCUSSION}

\section{Storm Analysis}

Climatic conditions of Sinai Peninsula are characterized by extreme aridity, long hot and rainless summer and a mild sporadic rainy winter. Rainfall is frequently occurring during the autumn (October and November) and winter (January and February) seasons. The temperature varies from $35.1^{\circ} \mathrm{C}$ in August and $18.75^{\circ} \mathrm{C}$ in winter (January). The potential evapotranspiration ranges from $5.5 \mathrm{~mm} /$ day in July to $1.9 \mathrm{~mm} /$ day in January. Relative humidity attains its maximum value (75\%) in August and minimum of 60\% in December (EMA, 1994).

Despite the fact that Sinai is classified as an arid zone and its water resources are limited, it is frequently subjected to heavy rainy storms, which produce flash floods. The flash floods cause many disasters for the main infrastructure in the study area, also play an important role in recharging the groundwater aquifers. In general, Wadi El Arish watershed receives an average annual rainfall volume of $981.3^{*} 10^{6} \mathrm{~m}^{3}$ in the rainy season (November - March), from which about $10.1 * 10^{6} \mathrm{~m}^{3}$ is downstream runoff (Gheith and Sultan, 2000). The Rwaffa storage Dam was constructed in

Egyptian J. Desert Res., 66, No. 1, 137-168 (2016) 
$1946,50 \mathrm{~km}$ to the south of El Arish city, with storage capacity of $3.0^{*} 10^{6}$ $\mathrm{m}^{3}$ of runoff water, in order to protect El Arish city from the effect of flash flood. The storage capacity of the dam has been increased in 1987 to hold $5.5^{*} 10^{6} \mathrm{~m}^{3}$ of water (Moawad, 2013).

Table (4) shows the history of flash flood events and its amount in Wadi El Arish during the last century, from 1947 to 1994 (Moawad, 2013), while table (5) shows the storm rainfall depth during the period of 1990 to 2000 in Sudr-Wardan area (Morad, 2000). From these tables the following can be noticed;

- Historically, in Wadi El Arish, 50\% of the recorded storm events occurred in late winter and spring seasons (February and March), while $50 \%$ occurred in winter season (November, December and January).

- Quantitatively, the estimated runoff volume in the late winter and spring seasons $\left(178.4 * 10^{6} \mathrm{~m}^{3}\right)$ is nearly ten times than that of the winter season $\left(15.08 * 10^{6} \mathrm{~m}^{3}\right)$

- In the storms of March 1947, March 1965 and February 1975, the amount of runoff water stored behind El Rafwaa Dam was 3.0*10 $\mathrm{m}^{3}$, while the rest of the runoff water passed the dam.

- In Sudr-Wardan area, the rainfall depth of the storm recorded in March represents the highest values in all the recorded data.

Table (4). Historical records of flash floods in Wadi El Arish (Moawad, 2013).

\begin{tabular}{lccc}
\hline Date & $\begin{array}{c}\text { Flood magnitude } \\
\left(\mathbf{1 0}^{\mathbf{6}} \mathbf{~ m}^{\mathbf{3}}\right)\end{array}$ & $\begin{array}{c}\text { Stored water behind } \\
\text { the dam } \\
\left(\mathbf{1 0}^{\mathbf{6}} \mathbf{~ m}^{\mathbf{3}}\right)\end{array}$ & $\begin{array}{c}\text { Discharge } \\
\left(\mathbf{1 0}^{\mathbf{6}} \mathbf{~ m}^{\mathbf{3}}\right)\end{array}$ \\
\hline March 1947 & 21 & 3.0 & 18 \\
February 1948 & 2.5 & 2.5 & \\
December 1949 & 0.5 & 0.5 & \\
March 1951 & 4.1 & 3.0 & 1.1 \\
December 1951 & 0.43 & 0.43 & \\
February 1952 & 0.40 & 0.40 & \\
March 1953 & 0.80 & 0.80 & 1.4 \\
November 1964 & 4.4 & 3.0 & 1.45 \\
11 December 1964 & 2.0 & 0.2 & 2.95 \\
14 December 1964 & 3.45 & 0.5 & \\
January 1965 & 0.5 & 0.5 & 27.0 \\
March 1965 & 30 & 3.0 & 117 \\
February 1975 & 120 & 3.0 & \\
November 1994 & 3.0 & 3.0 & \\
\hline
\end{tabular}


Table (5). Historical records of storm rainfall depths in Sudr-Wardan Area (Morad, 2000).

\begin{tabular}{lc}
\hline Date of Storm & Rainfall Depth $(\mathbf{m m})$ \\
\hline January 1990 & 15.50 \\
April 1990 & 9.14 \\
March 1991 & 30.50 \\
December 1991 & 6.43 \\
March 1994 & 20.67 \\
December 1998 & 4.70 \\
February 1999 & 15.30 \\
January 2000 & 8.15 \\
\hline
\end{tabular}

\subsection{The Storm of 17-18 January 2010}

In this research, two storms; January 2010, which represents the winter season in Sinai and March 2014, which occurred in spring season are selected to be analyzed. The rainfall data is collected from the websites for satellite data (NASA, 2010 and Global Weather, 2014).

The storm of January 2010 has great effects on Wadi El Arish and Wadi Wardan. From the field observation, during a field trip in Wadi El Arish after the storm, the following was noticed:

- Once the lake behind the Rafwaa Dam had stored $5.5^{*} 10^{6} \mathrm{~m}^{3}$ of water, therefore, the runoff water exceeded the height of the dam and the average height of the water was about $0.5 \mathrm{~m}$ over the dam. The runoff water passed the dam caused serious effects on El Arish city and its surrounding.

- Due to the physical settings of Delta Wadi El Arish, where its width is very narrow (5.0 km width only), the runoff in the Delta gets very strong with high velocity and the effect of such runoff on the drilled wells in the vicinity of the Delta is very limited.

- In Delta Wadi El Arish the monitoring results showed that after the flood, an average increase in the water levels was occurred with a range that varies between less than $10 \mathrm{~cm}$ and 2.3 meters, with decrease in water salinity (Shawki, 2011).

The duration of the storm was 30 hours; i.e. the storm began at 12:00 in 17 January until 18:00 in 18 January. In Wadi El Arish, the maximum rainfall was recorded at 17 January between 3:00 and 9:00, where it reaches $66.0 \mathrm{~mm}$ during six hours. The rainfall intensity of this storm was calculated and plotted for Wadi El Arish and Wadi Wardan (Fig. 8 and 9). The maximum rainfall intensity (peak of the storm) for Wadi El Arish was 2.2 $\mathrm{mm} / \mathrm{h}$ located at the central part of the wadi and decrease to the north and south direction. This maximum rainfall point is located at northern edge of El Egma plateau $\left(30^{\circ} 00^{\prime} 00^{\prime \prime} \mathrm{N}\right.$ and $\left.33^{\circ} 45^{\prime} 33^{\prime \prime} \mathrm{E}\right)$. The minimum rainfall 
intensity is $0.2 \mathrm{~mm} / \mathrm{h}$ located in the upstream part of wadi El Arish $\left(29^{\circ} 00^{\prime} 00^{\prime \prime} \mathrm{N}\right.$ and $\left.33^{\circ} 45^{\prime} 33^{\prime \prime} \mathrm{E}\right)$.

While, in Wadi Wardan, the maximum rainfall recorded was 31.95 $\mathrm{mm}$ between 15:00 to 21:00 at 17 January. The maximum rainfall intensity was $1.2 \mathrm{~mm} / \mathrm{h}$, located at point $29^{\circ} 50^{\prime} 00^{\prime \prime} \mathrm{N}$ and $33^{\circ} 15^{\prime} 00^{\prime \prime} \mathrm{E}$, which represents the midstream part of Wadi Wardan. The minimum was 0.40 $\mathrm{mm} / \mathrm{h}$, located in the southern part of the Wadi. It can be noticed from fig. (9) that the maximum rainfall is concentrated in the midstream of the Wadi (Lower Miocene Limestone) and decrease in the north, south and east direction.

Longitudinal profiles are plotting showing the relation between maximum rainfall $(\mathrm{mm})$ and elevation $(\mathrm{m})$ (above mean sea level) along the main trunk of the Wadies (Figs. 10,11). These profiles indicate that the rainfall behavior is not related to the elevation i.e. there isn't a direct relation between the rainfall values and the elevation. This is clear in the storm of 2010, where the peak of the storm is located in the midstream of the Wadies, where the elevation is medium; $365 \mathrm{~m}$ and $164 \mathrm{~m}$ for Wadi El Arish and Wadi Wardan respectively.

\subsection{The Storm of 10 March 2014}

In spite of this storm is less in magnitude and duration than the storm of 2010, it caused a great damage especially in the delta of Wadi Wardan (Abu Sewira town). The duration of this storm was $20 \mathrm{~h}$. The maximum rainfall was $29.26 \mathrm{~mm}$ in Wadi El Arish, while in Wadi Wardan, it was $19.0 \mathrm{~mm}$. Fig. (12 and 13) show the rainfall intensity distribution for this storm in the studied Wadies. It can be noticed that for Wadi El Arish, the maximum rainfall intensity $(1.46 \mathrm{~mm} / \mathrm{h})$ is located in the upstream of Wadi El Arish at the point of highest elevation in the Wadi and decrease to the north and west direction. While for Wadi Wardan, the maximum rainfall intensity was $0.95 \mathrm{~mm} / \mathrm{h}$ and located in the upstream of the wadi and decrease in the northwest direction.

From the longitudinal profiles of Wadi El Arish and Wadi Wardan (Fig. 14 and 15), the peak of the storm is located in the point of high elevation in the upstream of the Wadies; $1300 \mathrm{~m}$ for Wadi El Arish and 800 $m$ for Wadi Wardan.

Table (6) shows the main differences between the two storms on Wadi El Arish and Wadi Wardan. 


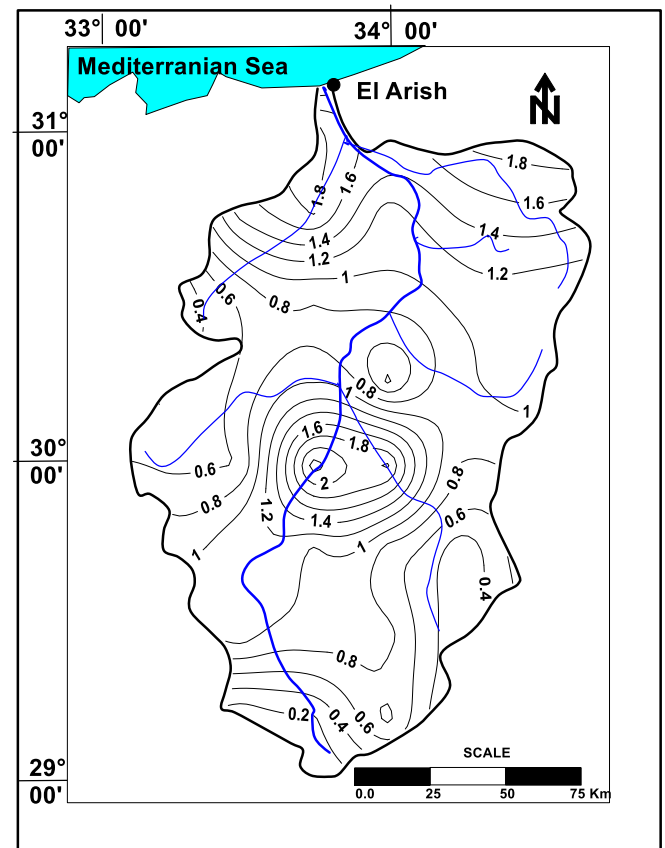

Fig. (8). Rainfall intensity distribution, El Arish (Jan. 2010).

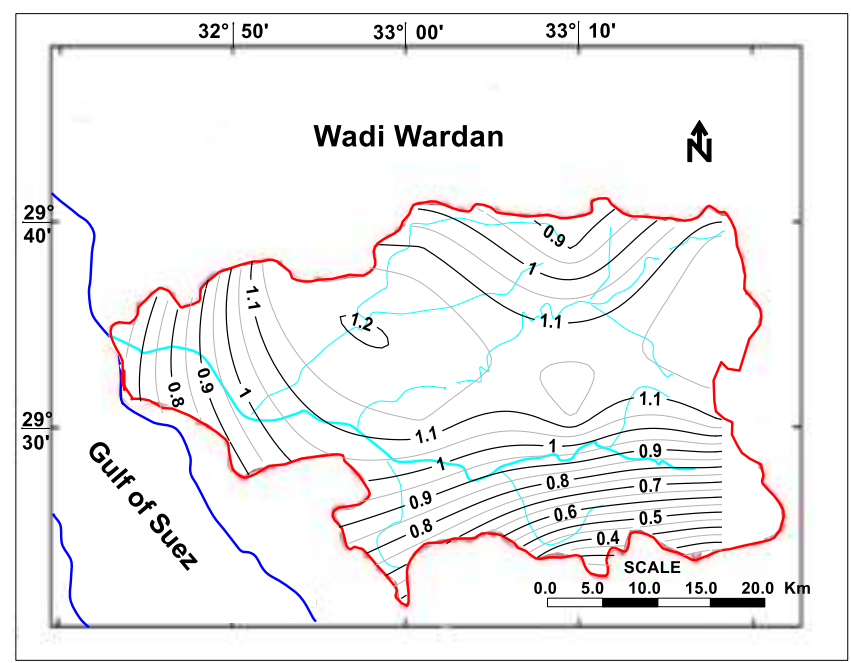

Fig. (9). Rainfall intensity distribution, Wardan (Jan. 2010).

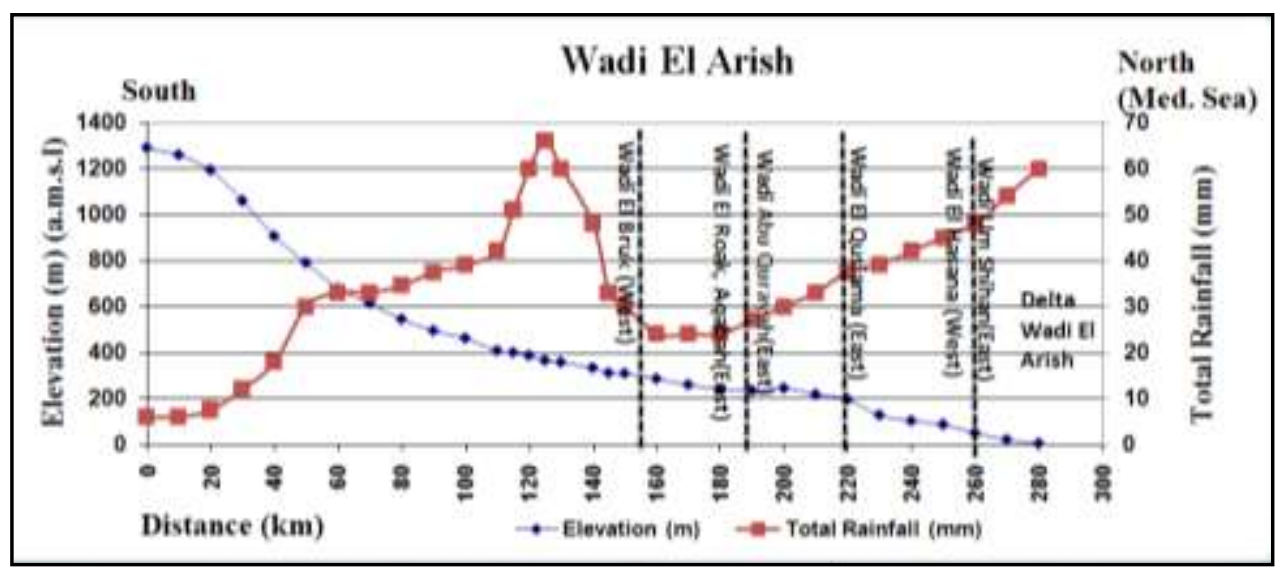

Fig. (10). Relation between elevation (m) and total rainfall (mm), January 2010 (Wadi El Arish).

Egyptian J. Desert Res., 66, No. 1, 137-168 (2016) 


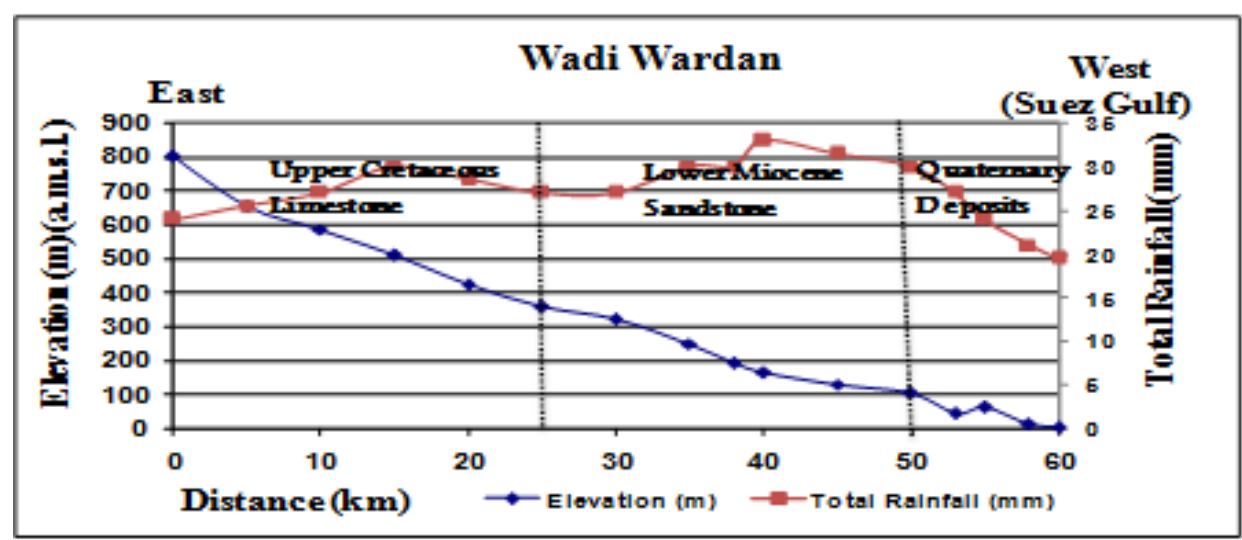

Fig. (11). Relation between elevation (m) and total rainfall (mm), January 2010 (Wadi Wardan).

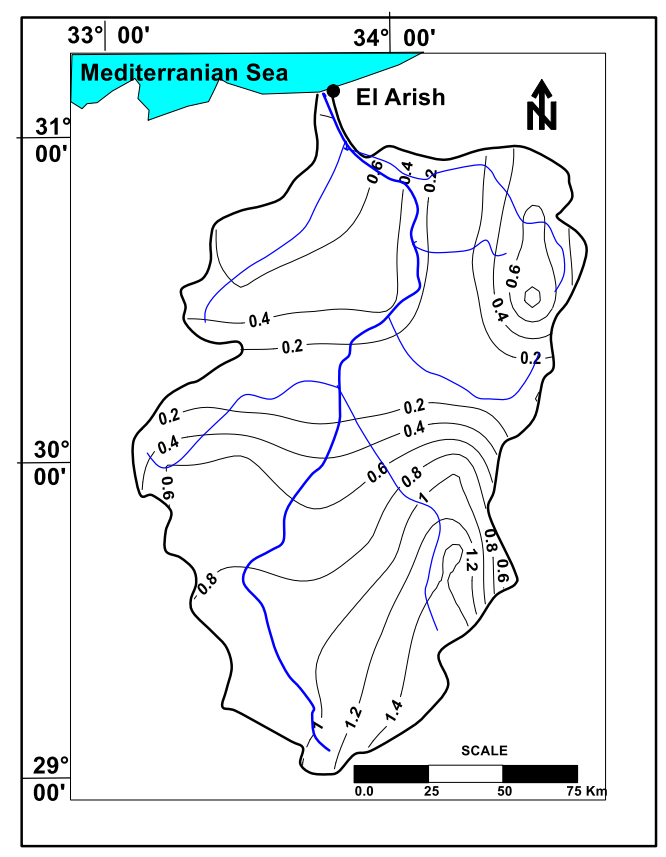

Fig. (12). Rainfall intensity distribution, El Arish (March 2014).

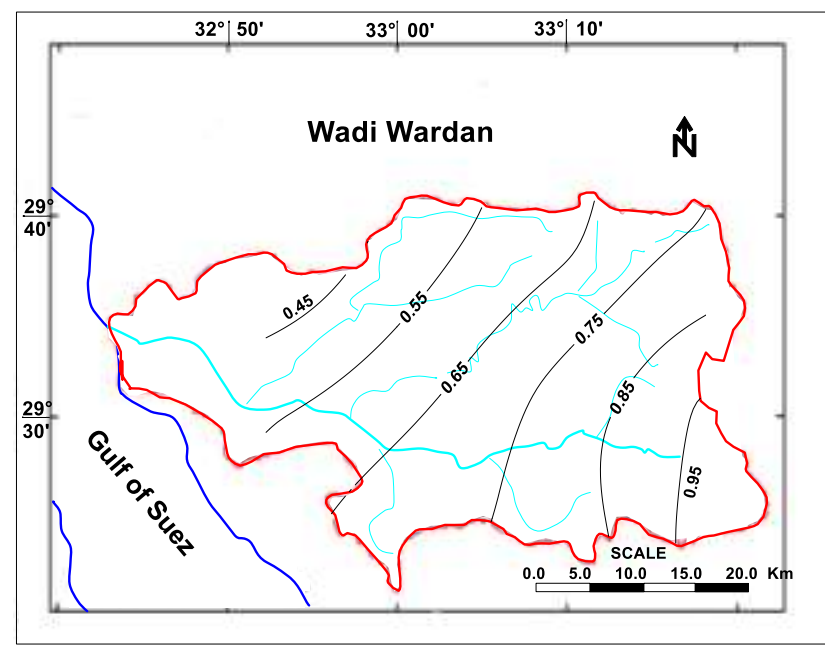

Fig. (13). Rainfall intensity distribution, Wardan (March 2014). 


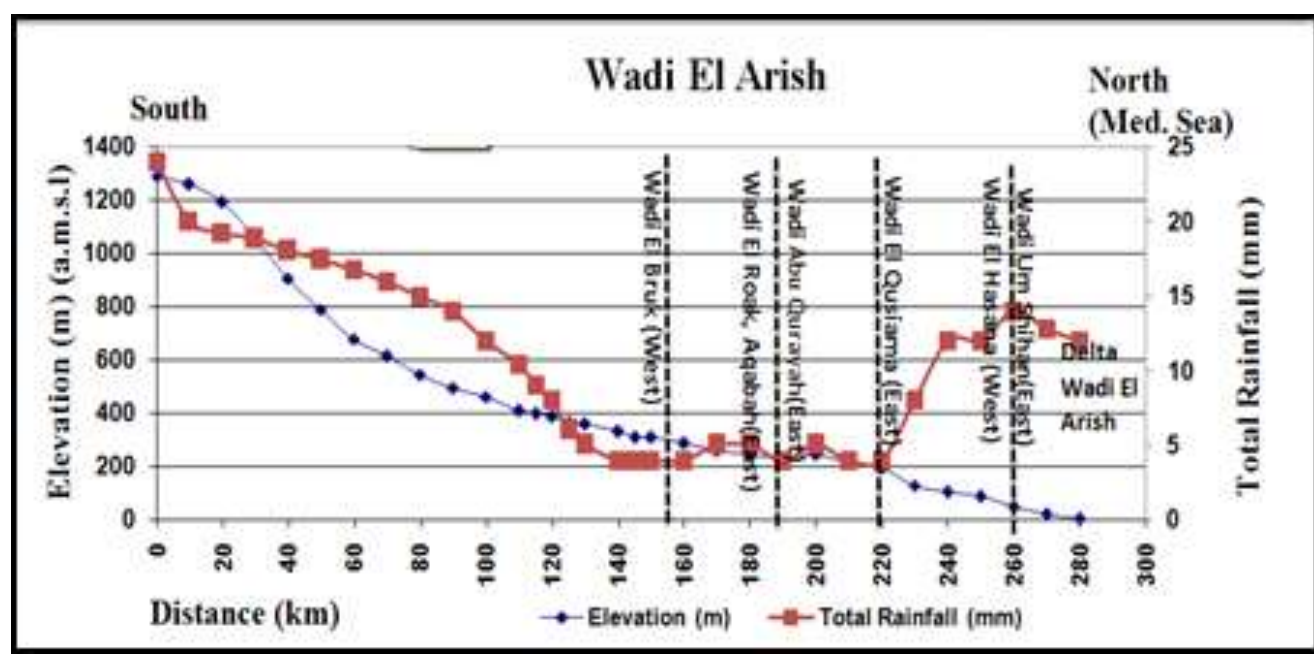

Fig. (14). Relation between elevation (m) and total rainfall (mm), March 2014 (Wadi El Arish).

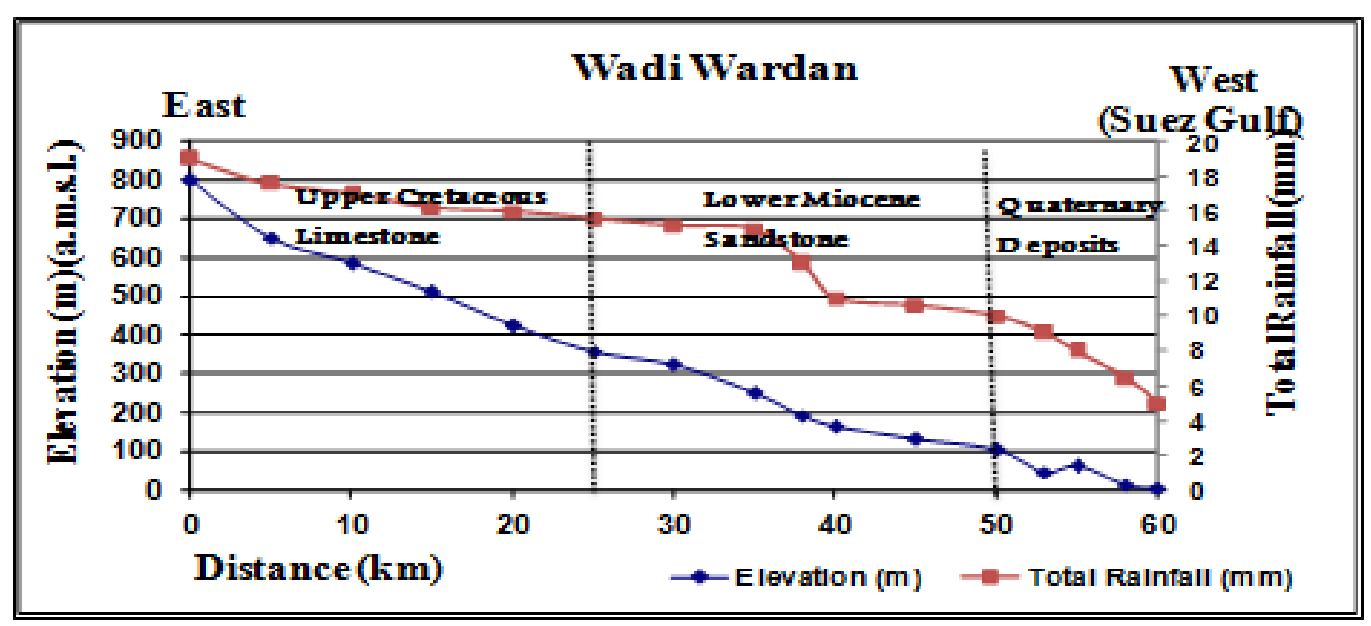

Fig. (15). Relation between elevation (m) and total rainfall (mm), March 2014 (Wadi Wardan).

Egyptian J. Desert Res., 66, No. 1, 137-168 (2016) 
Table (6). Comparison between the storms of 2010 and 2014.

\begin{tabular}{|c|c|c|c|c|c|}
\hline \multirow{3}{*}{\multicolumn{2}{|c|}{ Parameter }} & \multirow{2}{*}{\multicolumn{2}{|c|}{$\begin{array}{c}7 \text {-18 January } 2010 \\
\text { Winter storm }\end{array}$}} & \multirow{2}{*}{\multicolumn{2}{|c|}{$\begin{array}{l}10 \text { March } 2014 \\
\text { Spring storm }\end{array}$}} \\
\hline & & & & & \\
\hline & & Wadi El Arish & $\begin{array}{c}\text { Wadi } \\
\text { Wardan }\end{array}$ & $\begin{array}{l}\text { Wadi El } \\
\text { Arish }\end{array}$ & $\begin{array}{c}\text { Wadi } \\
\text { Wardan }\end{array}$ \\
\hline \multirow{3}{*}{\multicolumn{2}{|c|}{$\begin{array}{l}\text { Duration (hours) } \\
\text { Maximum rainfall }(\mathrm{mm}) \\
\text { Maximum rainfall } \\
\text { intensity }(\mathrm{mm} / \mathrm{h})\end{array}$}} & 30 & 30 & 20 & 20 \\
\hline & & 66.00 & 31.95 & 29.26 & 19.00 \\
\hline & & 2.2 & 1.1 & 1.46 & 0.95 \\
\hline \multirow{2}{*}{$\begin{array}{l}\text { Center } \\
\text { of storm } \\
\text { (Peak) }\end{array}$} & $\begin{array}{l}\text { Distance from } \\
\text { the upstream } \\
(\mathrm{km})\end{array}$ & 125 & 40 & $\begin{array}{c}\text { Zero } \\
\text { (Upstream of } \\
\text { the wadi) }\end{array}$ & $\begin{array}{c}\text { Zero } \\
\text { (Upstream of } \\
\text { the wadi }\end{array}$ \\
\hline & Elevation (m) & 365 & 164 & 1300 & 800 \\
\hline
\end{tabular}

\section{Catchment Modeling}

The Hydrologic Engineering Center-Hydrologic Modeling System (HEC-HMS version 4, 2010) software is applied to analyze and simulate the surface runoff storms. It is applied for El Arish and Wardan Wadies. In this study, the loss estimation methods and the lag-time computation methods is used in order to get the suitable parameters for rainfall-runoff relationship. The main elements in this program are:

- Basin model: including the different elements of water system (area of sub-basin, Lag time, Initial losses, etc.).

- Meteorological model: concerning with rainfall data including (rainfall value, distribution and duration).

- Control Specification: including the start and end of date and time (duration) of the concerned storm.

\subsection{Model input data}

\subsubsection{Catchment area}

According to the geological and morphmetrical characteristic of the studied Wadis, Wadi El Arish and Wadi Wardan are subdivided into a number of sub-basins as mentioned before (Tables 1 and 2). From these tables, the data of sub-basins area for each Wadi; including catchment area $\left(\mathrm{km}^{2}\right)$, basin length $(\mathrm{km})$ and average slope $(\mathrm{m} / \mathrm{km})$ are used as input data for the model (Table 7).

\subsubsection{Rainfall data}

The recorded data of the two storms (17-18 January 2010 and 10 March 2014) are used in the HEC-HMS model. The start and end of date and time of each storm are entered as input data in the model. The precipitation-time distribution are entered with a time step of three hours (Table 7). 


\subsubsection{Losses calculation}

Rainfall, which doesn't contribute to direct runoff, is considered to be a rainfall loss (Ponce, 1989). The initial loss (Ia) is empirically derived from the maximum soil water retention (S), which is related to the soil drainage characteristics (e.g. CN values). (Ia) accounts normally for losses due to evaporation, plant uptake, and water retained in surface depressions during the rainfall event. (S) accounts for the total amount of water retained in the drainage basin during the rainfall event. Soil Conservation Service (SCS, 1986) method is applied for losses calculations. The equations used for the calculation of initial loss are as follows:-

Where; $\quad \mathbf{Q}=\frac{(\boldsymbol{P}-\mathbf{0 . 2 S})^{2}}{(\boldsymbol{P}+\mathbf{0 . 8 S})} . \quad \ldots \mathrm{P}>0.2 \mathrm{~S}$

$\mathrm{Q}=$ Surface runoff depth $(\mathrm{mm})$

$\mathrm{P}=$ Total Rainfall depth $(\mathrm{mm})$

$\mathrm{S}=$ the potential retention parameter or surface storage after runoff begins

$(\mathrm{mm})$ that is a function of an empirical curve number $\mathrm{CN}$ coefficient where;

$$
\mathrm{S}=\frac{25400}{C N}-254
$$

The Curve Number $(\mathrm{CN})$ is a coefficient that expresses the runoff potential of the area. It is a function of the moisture condition, the land use, the hydrologic condition and the soil type. The range of the Curve Number $(\mathrm{CN})$ is obtained from standard tables according to the soil type and cover of each basin. The curve number is always less than 100. High curve numbers (>90) represent little or no infiltration, while low curve numbers $(<50)$ represent pervious surfaces. According to (SCS, 1986) classification of hydrologic soils, the Quaternary deposits in the study area were classified as type A soil with curve number of 63-70, while the sandstone and marl deposits of Miocene rocks were classified as type B, which has curve number of 77-80 and the fractured limestone (Upper Cretaceous rocks) as type $\mathrm{C}$ with a curve number $80-88$. A weighted average $\mathrm{CN}$ is calculated according to percentage of the total sub-catchment area with its corresponding $\mathrm{CN}$ using the following equation (Table 7):

$$
\mathrm{CN}=\sum_{i=1}^{k} A_{i} C N_{i} / \sum_{i=1}^{k} A_{i}
$$

$C N_{i}$ corresponds to the appropriate $\mathrm{CN}$ for the part of watershed that has an area $A_{i}$.

\subsubsection{Lag time calculation}

Lag time is an important factor for quantifying the time response of runoff in a given basin. It is defined as the time interval from the center of Egyptian J. Desert Res., 66, No. 1, 137-168 (2016) 
mass of rainfall excess to the center of the peak of runoff hydrograph (Granato, 2010). Catchment lag is empirically related to catchment characteristics. The lag-time can be calculated according to the following equation (Ponce, 1989);

$$
T_{L}=C\left(\frac{L L_{C}}{S^{0.5}}\right)^{N}
$$

Where:

$T_{L}=$ Catchment lag time (hours.)

$L=$ Basin length (length measured along the main stream from outlet to divide

$L_{C}=$ length to the centroid (length measured along main stream from outlet to a point located closed to the catchment centroid)

$S=$ slope of the basin $(\mathrm{m} / \mathrm{km})$

$C$ and $N$ are empirical parameters determined according to the catchment surface type. In case of mountain drainage areas, the estimated values for $\mathrm{C}$ and $\mathrm{N}$ are 0.35 and 0.38 respectively (Table 7 ).

Table (7). Main Elements as input in HEC-HMS for sub-basins of Wadi El Arish and Wadi Wardan.

\begin{tabular}{|c|c|c|c|c|c|c|c|c|}
\hline \multirow{2}{*}{$\begin{array}{c}\text { Name of } \\
\text { basin }\end{array}$} & \multirow{2}{*}{ Sub-basin } & \multirow{2}{*}{$\begin{array}{c}\text { Sub basin } \\
\text { area } \\
\left(\mathbf{k m}^{2}\right)\end{array}$} & \multicolumn{2}{|c|}{$\begin{array}{c}\text { Rainfall } \\
\text { depth }(\mathbf{m m})\end{array}$} & \multirow{2}{*}{$\mathbf{C N}$} & \multirow{2}{*}{$\begin{array}{l}\text { Potential } \\
\text { abstraction } \\
\text { (S) }\end{array}$} & \multirow{2}{*}{$\begin{array}{c}\text { Initial } \\
\text { loss } \\
\text { Ia }(\mathbf{m m})\end{array}$} & \multirow{2}{*}{$\begin{array}{c}\text { Lag } \\
\text { time } \\
\left(\mathrm{T}_{\mathrm{L}}\right) \\
\text { (hours) }\end{array}$} \\
\hline & & & $\begin{array}{l}\text { Jan. } \\
2010\end{array}$ & $\begin{array}{l}\text { Mar. } \\
2014\end{array}$ & & & & \\
\hline \multirow{8}{*}{ El Arish } & El Hasana & 3600 & 37.5 & 13.60 & 73.5 & 91.58 & 18.32 & 5.29 \\
\hline & El Bruk & 3310 & 38.5 & 10.67 & 76.8 & VY.VT & 15.35 & 5.74 \\
\hline & El Roak & 5988 & 37.2 & 14.00 & 83.5 & 50.19 & 10.04 & 9.00 \\
\hline & Aqabah & 2267 & 18.5 & 24.50 & 75.2 & 83.77 & 16.75 & 6.42 \\
\hline & Abu Qurayah & 3220 & 33.5 & 10.04 & 78.0 & 71.64 & 14.33 & 4.99 \\
\hline & El Qusiama & 1145 & 29.5 & 18.20 & 78.5 & 69.57 & 13.91 & 4.83 \\
\hline & $\begin{array}{l}\text { Umm- } \\
\text { Shihan }\end{array}$ & 2140 & 37.7 & 18.20 & 75.7 & 81.54 & 16.31 & 9.86 \\
\hline & Delta & 117 & 50.3 & 15.60 & 68.0 & 119.53 & 23.91 & 2.20 \\
\hline \multirow{4}{*}{ Wardan } & Somar & 441 & 34.6 & 15.80 & 80.0 & 63.50 & 12.70 & 2.98 \\
\hline & El Fawqiyah & 476 & 26.7 & 12.40 & 81.0 & 59.58 & 11.92 & 3.42 \\
\hline & El Rahah & 212 & 32.8 & 12.40 & 83.0 & 52.02 & 10.40 & 2.34 \\
\hline & Delta & 256 & 19.2 & 10.60 & 77.0 & 75.87 & 15.17 & 2.20 \\
\hline
\end{tabular}

\subsubsection{Routing method}

Routing is the movement of the runoff from the different watersheds outlets throughout the system along the stream, and ultimately to the outlet or sink of the entire watershed system (Chow et al., 1988). The HEC-HMS 
model routing options include the Muskingum, Modified Plus, Kinematic Wave, and Muskingum-Cunge methods. The routing method used in this work is Muskingum method, which get the best results. The key parameters in Muskingum routing are $\mathrm{K}$ (travel time) and $\mathrm{X}$ (weighting of coefficient). The Value of $\mathrm{X}$ depends on the shape of the wedge storage to be modeled, and ranges from 0 for reservoir-type storage to 0.5 for a full wedge. In natural streams, $\mathrm{X}$ is between 0 and 0.3 with a mean value near 0.25 . $\mathrm{K}$ is the time required for an incremental flood wave to traverse its reach, and it may be estimated as the observed time of travel of peak flow through the reach. The following values were used in the program:

$X=0.25 \quad \mathrm{~K}=0.55$

\section{Hydrograph Generation}

All the above data are used to generate runoff hydrographs for each sub-basin in Wadi El Arish and Wadi Wardan, for the two storm events (January 2010 and March 2014), in order to identify the relation between the rainfall and runoff and to estimate the runoff volume. The results are plotted and discussed as follows;

\section{Wadi El Arish}

For each sub-basin of Wadi El Arish (Fig. 16), the peak discharge and runoff volume are calculated and the hydrographs are plotted for the two storms (Table 8). The runoff depth and runoff coefficient are calculated using the following equations (Ponce, 1989):

$$
\begin{aligned}
\text { Runoff Depth } & =\frac{\text { Runoff Volume }}{\text { Drainage area }} \\
\text { Runoff Coeff } . & =\frac{\text { Runoff Depth }}{\text { Rainfall Depth }} \ldots \ldots
\end{aligned}
$$

The runoff coefficient is the relation between the runoff depth and rainfall depth, which represent the amount of rainfall transmitted to runoff.

The results show that Wadi El Arish receives a huge amount of runoff water during the storm of $2010\left(107.68 * 10^{6} \mathrm{~m}^{3}\right)$, with peak discharge equals to $1382.5 \mathrm{~m}^{3} / \mathrm{s}$. In the storm of 2014 the total runoff volume was $16.1 * 10^{6} \mathrm{~m}^{3}$ and the peak discharge was $279.1 \mathrm{~m}^{3} / \mathrm{s}$. Wadi El Roak (5988 $\mathrm{km}^{2}$ ), which represents the largest sub-basin in Wadi El Arish, produced the maximum runoff for the two storms.

To indentify the most severe sub-basin for flash flood, Wadi El Arish was subdivided into three main categories according to the flow direction (table 9) as follows;

- El Roak sub-basin $\left(5988 \mathrm{~km}^{2}\right)$, which represents about $27.5 \%$ of the total area of Wadi El Arish and runs from south to north.

Egyptian J. Desert Res., 66, No. 1, 137-168 (2016) 
- El Bruk and El Hassana sub-basins (32.7\%) and running from west to east

- Aqabah, Abu Qurayah, El Qussiama and Umm Shihan subbasins $(40.3 \%)$ and running from east to west.

From table (9), the following can be concluded;

- For storm 2010, it can be noticed that the runoff volume flows from south to north $\left(61.6^{*} 10^{6} \mathrm{~m}^{3}\right)$ represents about doubled that coming from the west and east $\left(24.6^{*} 10^{6} \mathrm{~m}^{3}\right.$ and $21.0^{*} 10^{6} \mathrm{~m}^{3}$ respectively).

- The peak discharge produced from the west and east sub-basins are almost equal $\left(489.6 \mathrm{~m}^{3} / \mathrm{s}\right.$ and $\left.447.7 \mathrm{~m}^{3} / \mathrm{s}\right)$, while the peak discharge coming from the south $\left(996.2 \mathrm{~m}^{3} / \mathrm{s}\right)$, represents, doubled that coming from the west and east.

- For storm 2014, the maximum runoff volume is coming from the south sub-basins (El Roak). It was noticed that, when the rainfall depth is less than the initial loss of the soil $(10 \mathrm{~mm})$ no runoff was produced. This is very clear for the west sub-basins, where the runoff volume is equal zero.

- The highest values for runoff depth and runoff coefficient, for the two storms (2010 and 2014), are in El Roak sub-basin, where the runoff coefficient is $27.65 \%$ and $15.88 \%$ for storm 2010 and 2014, respectively. This means that more than $27 \%$ of the rainfall transform to runoff.

In conclusion, El Roak sub-basin represents the most severe subbasin in Wadi El Arish. A proposed storage dam is suggested in the outlet of Wadi El Roak, which represents the point of intersection of three sub-basins (El Roak, El Bruk and Aqabah), in order to store the flood water and protect El Arish city from flood risk. 


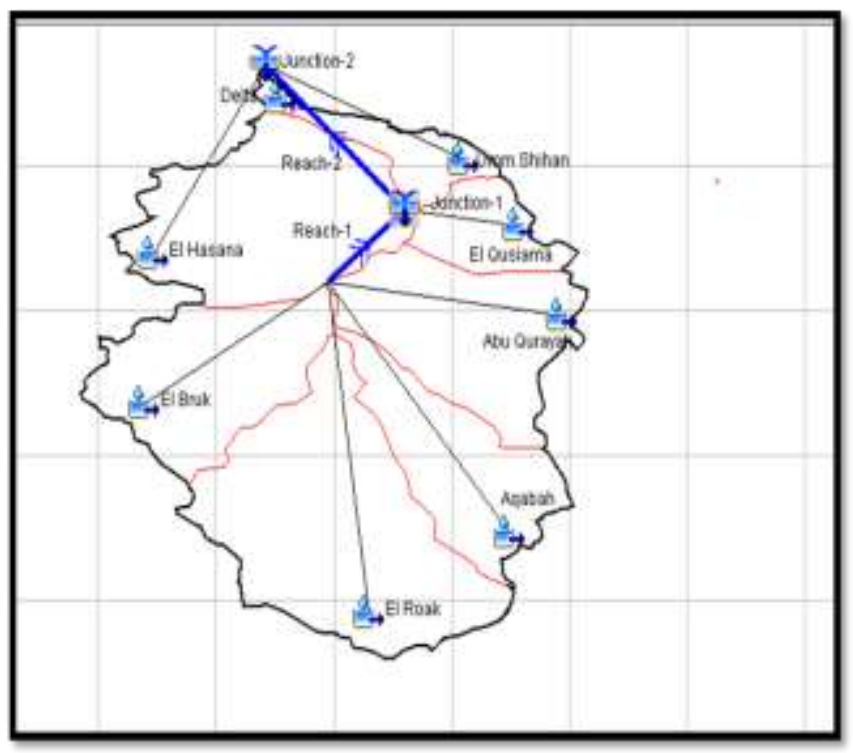

Fig. (16). Drainage basins of Wadi El Arish using hydrologic model (HECHMS).

Table (8). Output parameters of Wadi Arish basins for hydrograph generation using HEC-HM.

\begin{tabular}{|c|c|c|c|c|c|c|c|c|c|}
\hline \multirow[b]{2}{*}{ Name } & \multirow[b]{2}{*}{$\begin{array}{l}\text { Area } \\
\left(\mathbf{k m}^{2}\right)\end{array}$} & \multicolumn{4}{|c|}{ Storm January 2010} & \multicolumn{4}{|c|}{ Storm January 2014} \\
\hline & & $\begin{array}{c}\text { Peak } \\
\text { discharge } \\
\left(\mathbf{m}^{3} / \mathbf{s}\right)\end{array}$ & $\begin{array}{c}\text { Runoff } \\
\text { volume } \\
\left(10^{6} \mathrm{~m}^{3}\right)\end{array}$ & $\begin{array}{c}\text { Runoff } \\
\text { depth } \\
(\mathbf{m m})\end{array}$ & $\begin{array}{c}\text { Runoff } \\
\text { coeff. } \\
(\%)\end{array}$ & $\begin{array}{c}\text { Peak } \\
\text { discharge } \\
\left(\mathbf{m}^{3} / \mathbf{s}\right)\end{array}$ & $\begin{array}{c}\text { Runoff } \\
\text { volume } \\
\left(10^{6} \mathrm{~m}^{3}\right)\end{array}$ & $\begin{array}{c}\text { Runoff } \\
\text { depth } \\
(\mathbf{m m})\end{array}$ & $\begin{array}{c}\text { Runoff } \\
\text { coeff. } \\
(\%)\end{array}$ \\
\hline El Roak & 0911 & $997 . Y$ & 61.59 & 10.29 & 27.65 & rYq.q & 13.31 & 2.22 & 15.88 \\
\hline El Bruk & 洪. & r.r. & 14.79 & 4.47 & 11.61 & $\because$ & $\because .0$ & 0.00 & 0.00 \\
\hline Abu Qurayah & TrY. & ros.A & 9.78 & 3.04 & 9.07 & $\because$ & $\because 0$ & $\because \cdots$ & $\because \cdots$ \\
\hline Aqabah & TrTV & rч. & 1.26 & 0.56 & 3.06 & 01.1 & 2.68 & 1.18 & 4.83 \\
\hline Reach1 & $1 \leqslant \vee \wedge 0$ & IrrA.A & 87.42 & - & - & rVY. 9 & 15.99 & - & - \\
\hline El Qusiama & $11 \leq 0$ & or.1 & 23.90 & 2.09 & 7.08 & r. & 970.0 & 0.08 & 0.46 \\
\hline Junction1 & 1094. & Irra.r & 89.81 & - & - & rvq.० & 16.09 & - & - \\
\hline Reach2 & 1094. & ITrV. & 89.81 & - & - & rvq.1 & 16.09 & - & - \\
\hline El Hasana & (ז... & IVV.T & 9.83 & 2.73 & 7.29 & $\because$ & 0.00 & 0.00 & 0.00 \\
\hline Umm Shihan & rI $\leq$. & $11 \leq . \wedge$ & 7.60 & 3.55 & 9.43 & .1 & 0.003 & 0.03 & 0.16 \\
\hline $\begin{array}{c}\text { Delta } \\
\text { Junction2 }\end{array}$ & $11 \mathrm{~V}$ & 10. & 0.44 & r.vo & $V . \sum 7$ & $\because \cdot$ & 0.00 & $\because \cdots$ & 0.00 \\
\hline $\begin{array}{l}\text { (Outlet of } \\
\text { Wadi El } \\
\text { Arish) }\end{array}$ & YIVAV & IrAY.O & 107.68 & - & - & rvq.1 & 16.098 & - & - \\
\hline
\end{tabular}

Egyptian J. Desert Res., 66, No. 1, 137-168 (2016) 
Table (9). Comparison among different sub-basins in Wadi El Arish.

\begin{tabular}{|c|c|c|c|c|}
\hline \multirow[b]{2}{*}{ Basin flow direction } & \multicolumn{2}{|c|}{ Storm 2010} & \multicolumn{2}{|c|}{ Storm 2014} \\
\hline & $\begin{array}{c}\text { Peak } \\
\text { discharge } \\
\left(\mathbf{m}^{3} / \mathbf{s}\right)\end{array}$ & $\begin{array}{c}\text { Runoff } \\
\text { volume } \\
\left(\mathbf{1 0 0 0} \mathbf{~ m}^{3}\right)\end{array}$ & $\begin{array}{c}\text { Peak } \\
\text { discharge } \\
\left(\mathbf{m}^{3} / \mathbf{s}\right)\end{array}$ & $\begin{array}{c}\text { Runoff } \\
\text { volume } \\
\left(1000 \mathbf{~ m}^{3}\right)\end{array}$ \\
\hline South - North & $997 . r$ & $710 \wedge 9.1$ & 229.9 & 13314.5 \\
\hline West - East & 489.6 & 24623.7 & 0.0 & 0.0 \\
\hline East - West & 447.7 & 21043.3 & 54.9 & 2687.4 \\
\hline
\end{tabular}

The computed runoff hydrograph of El Arish basin for the storms 2010 and 2014 are plotted (Fig. 17 and 18), the results extracted from these figures are shown in table (10), where the following can be distinguished:

\section{For Storm January 2010}

- $\quad$ There is a lag time of 2 hours between the start of the storm and the start of runoff

- $\quad$ The duration of the runoff was $52 \mathrm{~h}$, i.e. the runoff continued for 22 hours after the end of the storm.

- $\quad$ The runoff reaches its maximum $\left(1382.5 \mathrm{~m}^{3} / \mathrm{s}\right)$ at 18 January at $10: 00$, i.e. the time to reach the maximum discharge peak is 20 hours from the beginning of the runoff.

\section{For Storm March 2014}

- $\quad$ There is a lag time of 2 hours between the start of the storm and the start of runoff

- $\quad$ The duration of the runoff was 50 h, i.e. the runoff continued for 30 hours after the end of the storm.

- The runoff reaches its maximum $\left(279.1 \mathrm{~m}^{3} / \mathrm{s}\right)$ at 10 March at 22:00, i.e. after 10 hours from the start of runoff.

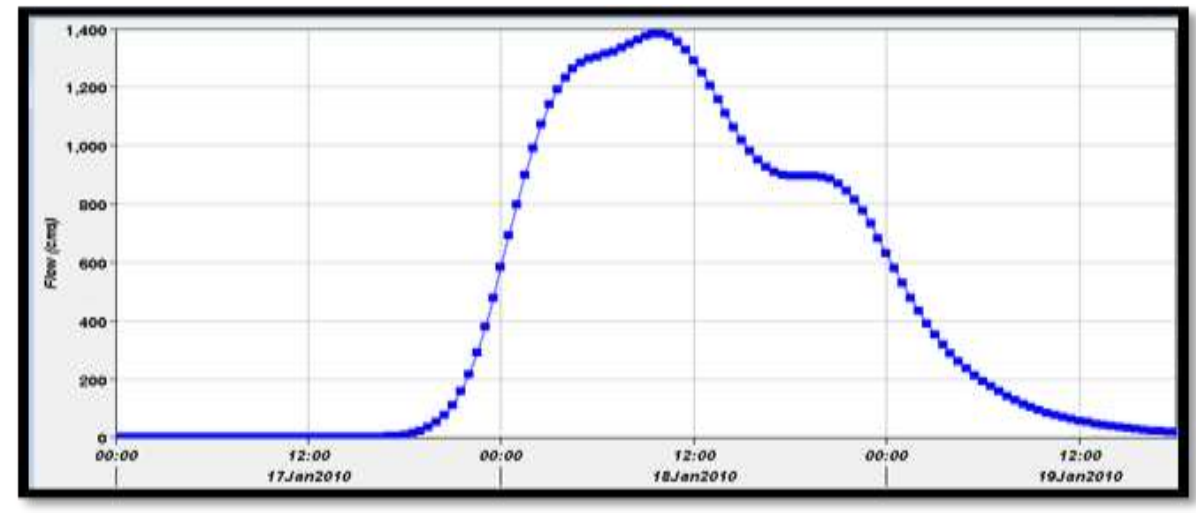

Fig. (17). Computed runoff hydrograph for Jan. 2010 storm of El Arish catchment. 


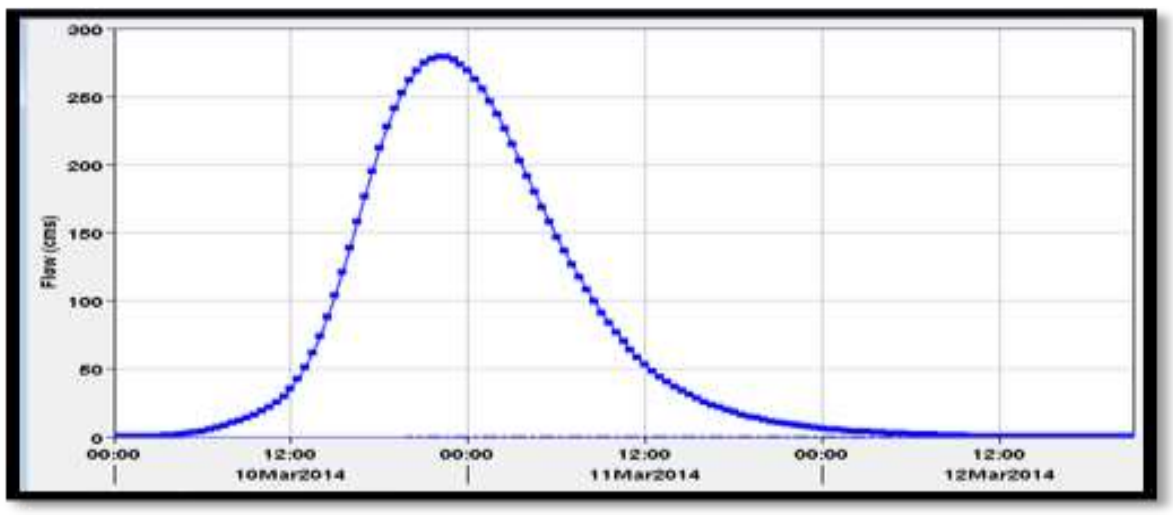

Fig. (18). Computed runoff hydrograph for March 2014 storm of El Arish catchment.

Table (10). Results of computed runoff hydrograph for Wadi El Arish.

\begin{tabular}{lcc}
\hline Parameters & Storm January 2010 & Storm March 2014 \\
\hline Start date of storm & 17 January 2010 & 10 March 2014 \\
Start time of storm & $12: 00$ & $0: 00$ \\
End date of storm & 18 January 2010 & 10 March 2014 \\
End time of Storm & $18: 00$ & $20: 00$ \\
Storm Duration (h) & 30 & 20 \\
Start date of runoff & 17 January 2010 & 10 March 2014 \\
Start time of runoff & $14: 00$ & $2: 00$ \\
End date of runoff & 19 January 2010 & 12 March 2014 \\
End time of runoff & $18: 00$ & $4: 00$ \\
Runoff Duration (h) & 52 & 50 \\
Date of Peak runoff & 18 January 2010 & 10 March 2014 \\
Time of Peak runoff & $10: 00$ & $22: 00$ \\
Peak runoff $\left(\mathrm{m}^{3} / \mathrm{s}\right)$ & 1382.5 & 279.1 \\
\hline
\end{tabular}

\section{Wadi Wardan}

This Wadi is divided into four sub-basins (fig. 19). For each subbasins, a hydrograph is calculated and plotted using all the available data. Table (11) shows the output parameters of Wadi Wardan, from which the following can be noticed:

- For the storm of January 2010, in the outlet of the Wadi, the peak discharge was $312 \mathrm{~m}^{3} / \mathrm{s}$ with runoff volume equal to $8.9^{*} 10^{6} \mathrm{~m}^{3}$

- For the storm of March 2014, the peak discharge was $52.1 \mathrm{~m}^{3} / \mathrm{s}$ and the runoff volume was $1.5 * 10^{6} \mathrm{~m}^{3}$.

- For the two storms (2010 and 2014), Somar sub - basin, which is located in the upstream of wadi Wardan and runs in east-west direction

Egyptian J. Desert Res., 66, No. 1, 137-168 (2016) 
gives the maximum discharge and consequently the maximum runoff volume.

- The delta of the wadi share with a very small part in the runoff volume $\left(0.037 * 10^{6} \mathrm{~m}^{3}\right)$

- The runoff depth ranges from $9.788 \mathrm{~mm}$ to $0.147 \mathrm{~mm}$ for storm 2010, while for storm 2014, the runoff depth is less $(1.3 \mathrm{~mm}$ to $0.69 \mathrm{~mm})$. The runoff coefficient varies between $36.55 \%$ to $0.76 \%$ for storm 2010 , which means that about $36 \%$ of rainfall is transmitted to runoff. For storm 2014, the values range from $13.04 \%$ to $5.6 \%$.

- For storm 2014, in the delta area, the runoff is equal zero where the rainfall depth $(10.6 \mathrm{~mm})$ is less than the initial loss $(15.17 \mathrm{~mm})$. In general, the rainfall depth must be greater than initial loss, in order to get runoff.

Fig. (19). Drainage basins of Wadi Wardan using hydrologic model (HEC-HMS).

Table (11). Output parameters of Wadi Wardan basins for hydrograph generation using HEC-HM.

\section{Storm January 2010}

\section{Storm January 2014}

\begin{tabular}{|c|c|c|c|c|c|c|c|c|c|}
\hline Name & $\begin{array}{l}\text { Area } \\
\left(\mathbf{k m}^{2}\right)\end{array}$ & $\begin{array}{c}\text { Peak } \\
\text { discharge } \\
\left(\mathbf{m}^{3} / \mathbf{s}\right)\end{array}$ & $\begin{array}{c}\text { Runoff } \\
\text { volume } \\
\left(\mathbf{1 0 0 0} \mathbf{~ m}^{3)}\right.\end{array}$ & $\begin{array}{c}\text { Runoff } \\
\text { depth } \\
(\mathbf{m m})\end{array}$ & $\begin{array}{c}\text { Runoff } \\
\text { coeff. } \\
(\%)\end{array}$ & $\begin{array}{c}\text { Peak } \\
\text { discharge } \\
\left(\mathbf{m}^{3} / \mathbf{s}\right)\end{array}$ & $\begin{array}{c}\text { Runoff } \\
\text { volume } \\
\left(1000 \mathbf{~ m}^{3}\right)\end{array}$ & $\begin{array}{c}\text { Runoff } \\
\text { depth } \\
\text { (mm) }\end{array}$ & $\begin{array}{c}\text { Runoff } \\
\text { coeff. } \\
(\%)\end{array}$ \\
\hline El Fawqiyah & 476 & 19.0 & YOMI. & $0 . V r q$ & 17.05 & $r \cdot .9$ & 094. & $1 . r \leqslant \varepsilon$ & $\Lambda . \varepsilon \wedge$ \\
\hline Somar & 441 & $11 \cdot .9$ & $\sum 709 . r$ & 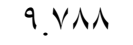 & 47.00 & rV. 1 & 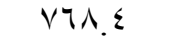 & $1.71 \leq$ & $1 \pi . \cdot \varepsilon$ \\
\hline El Rahah & 212 & Nr.o & IV.r.I & $\Lambda \cdot r \Lambda$ & 10.40 & $0 . V$ & $1 \leq 7.9$ & .793 & 0.7 \\
\hline Reach 1 & 1129 & 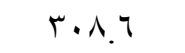 & ANAV.r & - & - & or. & $10.1 . r$ & - & - \\
\hline $\begin{array}{l}\text { Delta } \\
\text { Junction (1) }\end{array}$ & 256 & $\varepsilon . \varepsilon$ & rV.V & $\because 1 \leqslant V$ & $\because \vee 4$ & $\because$ & $\because$ & $\because \cdot$ & $\because \cdot$ \\
\hline $\begin{array}{l}\text { Outlet of } \\
\text { Wadi } \\
\text { Wardan }\end{array}$ & 1385 & 312.0 & $\wedge q r \leq . q$ & & & or." & $101 \leq .1$ & & \\
\hline
\end{tabular}


The computed runoff hydrographs for Wadi Wardan for the storms 2010 and 2014 are plotted (Fig. 20 and 21), the results extracted from these figures are shown in table (12), where the following can be distinguished:

For Storm January 2010

- $\quad$ There is a lag time of 1 hours between the start of the storm and the start of runoff

- $\quad$ The duration of the runoff was $r \cdot h$, i.e. the runoff continued for $1 \cdot$ hours after the end of the storm.

- The runoff reaches its maximum $\left(\Gamma / Y \mathrm{~m}^{3} / \mathrm{s}\right)$ at $1^{\vee}$ January at $r r: 00$, i.e. after $2 r$ hours from the start of runoff.

\section{For Storm March 2014}

- There is a lag time of 1.5 hours between the start of the storm and the start of runoff

- $\quad$ The duration of the runoff was 33 h, i.e. the runoff continued for 13 hours after the end of the storm.

- The runoff reaches its maximum $\left(52.0 \mathrm{~m}^{3} / \mathrm{s}\right)$ at 10 March at $14: 30$, i.e. after 13.5 hours from the start of runoff.

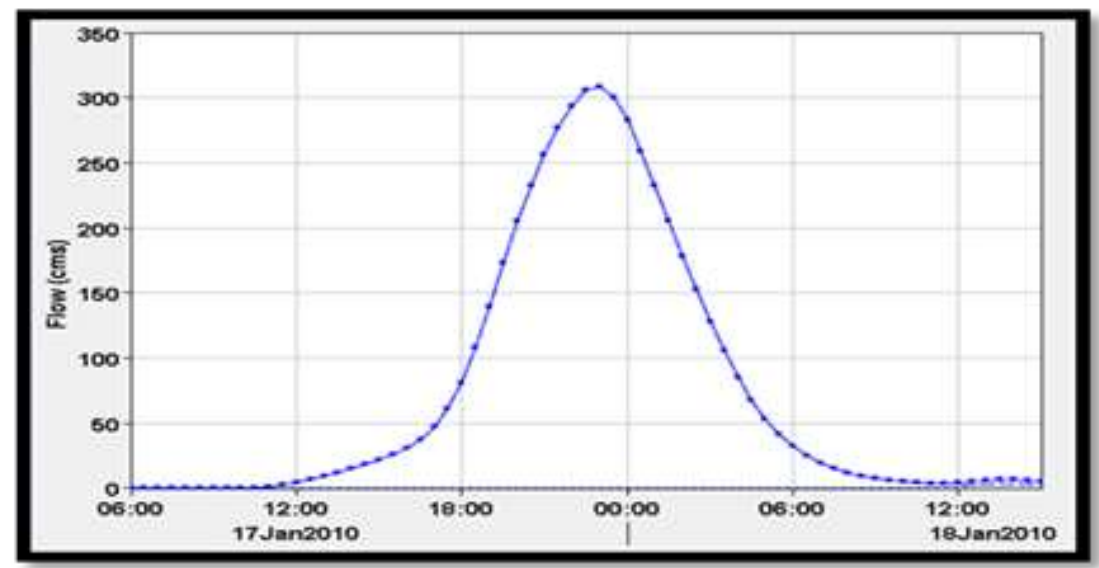

Fig. (20). Computed runoff hydrograph for January 2010 storm of Wardan. catchment. 


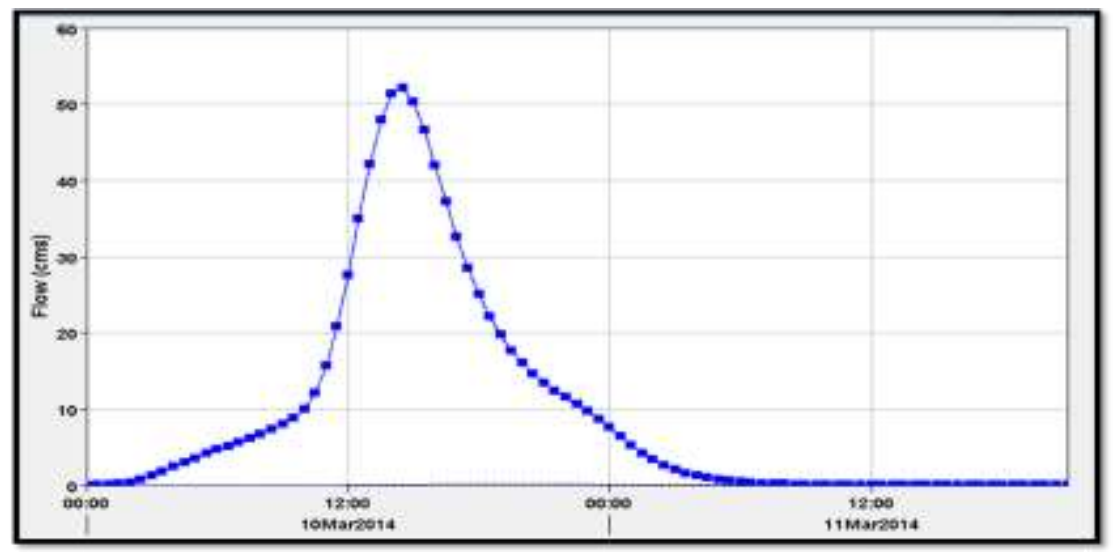

Fig. (21). Computed runoff hydrograph for March 2014 storm of Wardan catchment.

Table (12). Results of computed runoff hydrograph for Wadi Wardan.

\begin{tabular}{lcc}
\hline Parameters & Storm January 2010 & Storm March 2014 \\
\hline Start date of storm & 17 January 2010 & 10 March 2014 \\
Start time of storm & $12: 00$ & $0: 00$ \\
End date of storm & 18 January 2010 & 10 March 2014 \\
End time of Storm & $18: 00$ & $20: 00$ \\
Storm Duration (h) & 30 & 20 \\
Start date of runoff & 17 January 2010 & 10 March 2014 \\
Start time of runoff & $13: 00$ & $1: 30$ \\
End date of runoff & 18 January 2010 & 11 March 2014 \\
End time of runoff & $19: \cdot$. & $10: 30$ \\
Runoff Duration (h) & $r \cdot$ & 33 \\
Date of Peak runoff & 17 January 2010 & 10 March 2014 \\
Time of Peak runoff & $23: 00$ & $14: 30$ \\
Peak runoff $\left(\mathrm{m}^{3} / \mathrm{s}\right)$ & 312.0 & 52.0 \\
\hline
\end{tabular}

However, actual observed data for runoff are lacking in both Wadies, due to the absence of any hydraulic constructions for runoff measurement. This makes the calibration of the simulated data becomes difficult. Rainfall and runoff gages are needed everywhere in Sinai for runoff detection, protection and storage. On the other hand, the installation of telemetric meteorological stations on the upstream of the Wadies will help a lot for water resource studies, since there is a great lack of meteorological data in the area of study. 


\section{CONCLUSION}

In general, the analysis of rainfall storms indicates that they have not the same behavior neither spatially nor temporally, where they differ from one locality to another and from time to time. In other words, the behavior of both storms (2010 and 2014) are completely different, where in the storm of 2010, there is no obvious relation between the rainfall amount and the ground elevation of sub-basins, while for the storm of 2014, this relation is very prominent, where the points of maximum elevation receive the maximum rainfall.

In Wadi El Arish, El Roak sub-basin which run from the south to the north represent the largest sub-basin in area, and consequently gives the peak runoff rate and the maximum runoff volume. The summation of subbasins coming from the west (El Bruk and El Hassana) and those coming from the east (Aqabah, Abu Qurayah, El Qussiama and Umm Shihan) give runoff volume less than El Roak sub-basin, which represents the most severe runoff sub-basin in Wadi El Arish. A proposed storage dam is suggested in the outlet of Wadi El Roak, at the intersection of three subbasins (El Roak, El Bruk and Aqabah), in order to store the flood water and to replenish the shallow ground water aquifer.

In Wadi Wardan, Somar sub-basin, which is located in the upstream of Wadi Wardan and run east-west direction, gives the maximum discharge and consequently the maximum runoff volume. A proposed storage dam is also suggested in the outlet of Somar sub-basin, which intersects with the outlet of El Fawiqyah sub-basin.

\section{REFERENCES}

Abdel-Lattif, A. and Y. Sherief (2010). Morphometric analysis and flash floods of Wadi Sudr and Wadi Wardan, Gulf of Suez, Egypt: using digital elevation model. Arab J. Geosci., DOI 10.1007/s12517-0100156-8.

Abdel Monsef, H.M. (1991). Geological and hydrogeological study in Wadi El Arish basin using landsat images, M.Sc. Thesis, Faculty of Science, Suez Canal University, Egypt.

Abo Shaala, N.A. (2016). Hydrological assessment of Wadi Sudr and vicinities, South Sinai, Egypt. Ph.D. Thesis, Faculty of Science, Ain Shams University, Cairo, Egypt.

Arekhi, S. (2012). Runoff modeling by HEC-HMS model (Case Study: Kan watershed, Iran). International Journal of Agriculture and Crop Sciences, 4 (23): 1807-1811.

Choudhari, K., B. Panigrahi and J.C. Paul (2014). Simulation of rainfallrunoff process using HEC-HMS model for Balijore Nala watershed,

Egyptian J. Desert Res., 66, No. 1, 137-168 (2016) 
Odisha, India. International Journal of Geomatics and Geosciences, $5(2)$.

Chow, V.T., D.R. Maidment and L.W. Mays (1988). In “"Applied Hydrology". McGraw-Hill, New York, U.S.A.

Dames and Moore (1981). Land classification and capability in Sinai, Sinai Development Study, Phase 1" Report submitted to the Advisory Committee for Reconstruction of the Ministry of Development, Cairo, Egypt.

EMA (1994). Reports for meteorological data. Egyptian Meteorological Authority, 1988- 1994.

Fathy, I., M. Abdelazim, A.M. Negm, M. El-Fiky, M. Nassar and E. Al Sayed (2015). Runoff hydrograph modeling for arid regions. International Water Technology Journal, 5 (1).

Geological map of Sinai, Arab Republic of Egypt (1994). Sheet No. 2, 3, 4 and 5, Scale 1:250 000.

Gebre, S.L. (2015). Application of the HEC-HMS model for runoff simulation of Upper Blue Nile River Basin. Hydrol. Current Res., 6 (2): 1000199.

Gheith, H.M. and M.I. Sultan (2000). Assessment of the renewable groundwater resources of Wadi El Arish, Sinai, Egypt. Conference of Remote Sensing and Hydrology, Santa Fe. New Mexico, USA, 27 April 2000.

Global Weather (2014). Available online: http://globalweather.tamu.edu/.

Granato, G.E. (2010). In "Methods for Development of Planning-level Estimates of Storm Flow at Unmonitored Sites in the Conterminous United States". Washington, D.C., U.S. Department of Transportation, Federal Highway Administration.

Halwatura, D. and M.M. Najim (2013). Application of the HEC-HMS model for runoff simulation in a tropical catchment. Environmental Modeling and Software, 46: 155-162.

Hassan, M.A.A. (2002). Environmental studies on coastal zone soils of the north Sinai peninsula (Egypt) using remote sensing techniques. Ph.D. Thesis, Faculty of Agriculture, Suez Canal University, Egypt.

Hassanein, A.H. (1989). Geology of water resources in Wadi Sudr-Wadi Gharandal area, Gulf of Suez region, Sinai Peninsula, Egypt. M.Sc. Thesis, Faculty of Science, Ain Shams University, Cairo, Egypt.

HEC-HMS (2010). In "Hydrologic Modeling System HEC-HMS, version 4" US Army Corps of Engineers, Institute For Water Resources, Hydrologic Engineering Center, Davis, California.

ILWIS 3.4 (2007). "Integrated Land and Water Information System". International Institute for Aerospace Survey and Earth Sciences (ITC), Enschede, The Netherlands.

JICA (Japan International Cooperation Agency) (1999). South Sinai groundwater resources study in the Arab Republic of Egypt, Main

Egyptian J. Desert Res., 66, No. 1, 137-168 (2016) 
Report, Pacific Consultations International. Tokyo in association with sandy consultation, Tokyo.

Misak, R.F., S.M. Atwa, M.K. Sallouma and A.H. Hassanein (1995). Geology and water quality of the groundwater supplies in SudrGharandal area, Gulf of Suez, Egypt. Bull. Fac. Sci., Assiut Univ., 24 (2-F): 1-21.

Moawad, B.M. (2013). Analysis of the flash flood occurred on 18 January 2010 in wadi El Arish, Egypt (a case study). Geomatics, Natural Hazards and Risk, 4 (3): 254- 274.

Morad, N.A. (2000). Rainfall-runoff relationship in mountainous areas: Case Study Wadi Sudr", M.Sc. Thesis, Faculty of Engineering, Ain Shams University, Cairo, Egypt.

NASA (2010). Available online: hhttp://disc2.nascom.nasa.gov/Giovanni/tovas/.

Ponce, V.M. (1989). In "Engineering Hydrology, Principle and Practices". Prentice-Hall, New Jersey, U.S.A.

Sayed, M.A.A. and T.A. Abel Latif (1985). Evaluation of soil and water resources in Wadi Wardan, Sinai, Egypt using electrical resistivity method. Qatar University Science Bulletin, 5: 321-333.

Shabana, A.R. (2014.) Geologic factors controlling shallow groundwater occurrence in carbonate and sandstone rocks in some localities in Sinai Peninsula, Egypt. Egyptian Journal of Geology, 58: 21-39.

Shawki, S.H. (2011). Impact of flash floods on the hydrogeological aquifer system at delta Wadi El-Arish (North Sinai), Fifteenth International Water Technology Conference, IWTC -15, Alexandria, Egypt.

SCS (Soil Conservation Service) (1986). In "Hydrology Guide for Use in Watershed Planning". SCS National Engineering Handbook, Section 4: Hydrology. US Department of Agriculture, Soil Conservation Service, Engineering Division, Washington.

Received: 29/12/2016

Accepted: 26/2/2017

Egyptian J. Desert Res., 66, No. 1, 137-168 (2016) 


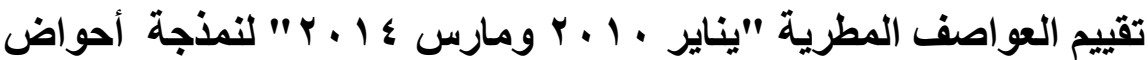 وادي العريش ووادي وردان، سيناء ـ ـ مصر الهر
}

\author{
نهلة عبد المنعم مراد \\ قسم الهيدرولوجيا، مركز بحوث الصحر اء، المطرية، القاهرة، مصر
}

يتناول هذا البحث العلاقة بين العواصف المطرية والجريان السطحي في بعض الوبر الوديان

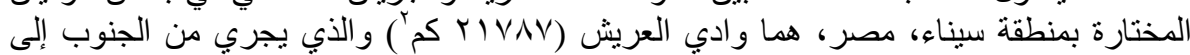

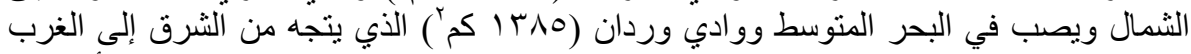

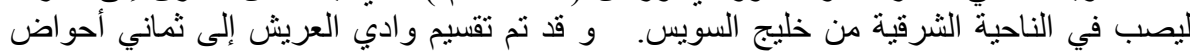

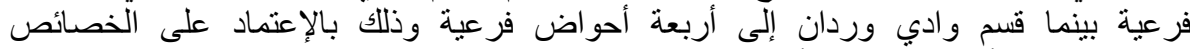

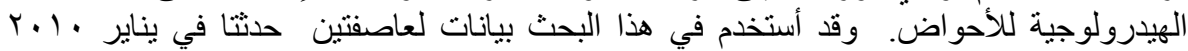

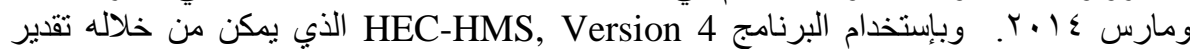

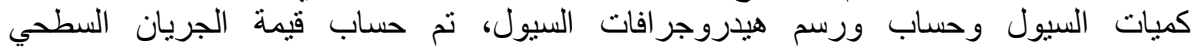

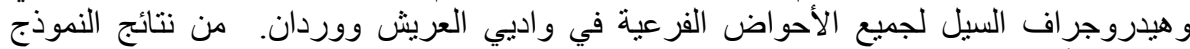

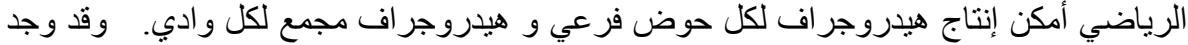

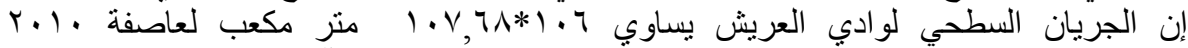

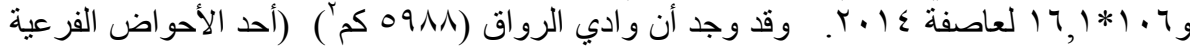

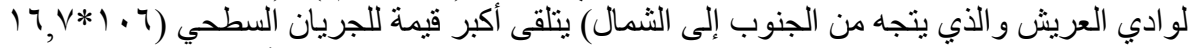

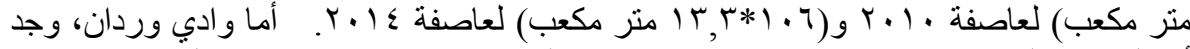

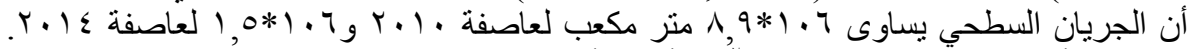

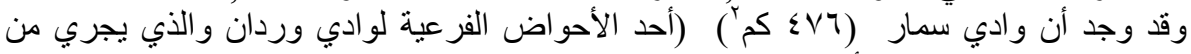

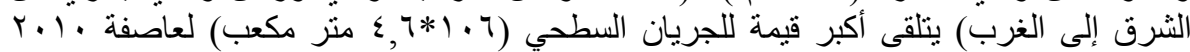

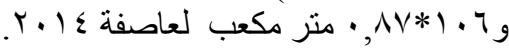

لحماية المناطق العمر انية و المدن من أخطار السيول، يقترح الباحث إنشاء سدود تخزينية

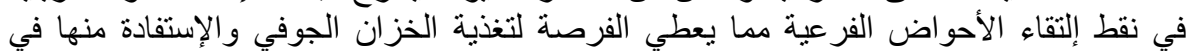
المثاريع الزر اعية لتنمية هذه المناطق. 